\title{
Derviş Zaim Sinemasında Anlatının Platformu Olarak Mekân: Anlatı, Sinemasal Gerilim ve Mekân İlişkisi
}

\author{
Aydın Çam (Dr. Öğr. Üyesi) \\ Çukurova Üniversitesi İletişim Fakültesi \\ aydinaksu@gmail.com
}

Başvuru Tarihi: 04.01.2018

Yayına Kabul Tarihi: 12.06.2018

Yayınlanma Tarihi: 30.07.2018

\section{Öz}

$\mathrm{Bu}$ çalıșmada olayların, olguların, karakterlerin varoluşlarını bulduğu sahne ve sinemasal eylemin gerçekleștiği platform olarak, Derviş Zaim filmlerindeki sinemasal mekânlar değerlendirilmektedir. Çalışmada Derviş Zaim'in filmografisi biçimsel ve bağlamsal yöntemlerle çözümlenmektedir. Bunun için yönetmenin filmleri, mekân bağlamında planlarına ayrılmış, nicel veri elde edilmiş; bu veriler gerektiği yerde tablolaştırılmış, şekil haline getirilmiş ya da görselleştirilmiştir. Elde edilen bu veriden, bağlamsal çözümleme gerçekleștirilirken yararlanılmıştır. Bununla birlikte yönetmenle gerçekleştirilen söyleşi ve görüşmeler içerik çözümlemesiyle nitel verilere dönüștürülerek çalışmaya dâhil edilmiştir. Çalışmada öncelikle yönetmenin sinematografisinin öğeleri olarak sinemasal mekânlar biçimsel çözümlemeye tabi tutularak yorumlanmıștır. Bunun ardından iç, dış ve ara mekânlar olarak sınıflandırılan farklı mekân tipleri arasında kurgunun/montajın olanaklarıyla, yönetmenin bir yandan sinemasal gerilimi yaratırken diğer yandan sinemasal anlamı nasıl dönüștürdüğü yorumlanmıştır.

Derviş Zaim sinemasını mekân bağlamında değerlendiren bu çalışmada özetle şu sonuca ulaşılmıştır: Derviş Zaim sinemasında mekân, film deviniminin asli öğesi ve anlatının platformu olarak, anlatının devinimine denk bir biçimde kullanılmaktadır. İç ve dış mekân geçişleriyle sinemasal anlatı zenginleştirilmekte ve mekân sadece sinemasal anlatıya platform oluşturmakla kalmayarak bizatihi anlatıyı ileri taşıyan sinemasal gerilimi oluşturmak için kullanılmaktadır. Yönetmen, iç ve dış mekânlar arasındaki gerilimi öykünün gerilimine taşımaktadır. Gerilim bir yandan mekânları birleștiren bir öğe haline gelirken mekân da hem gerilime hem de filmin anlatısına bir platform teşkil etmektedir. Mekân, gerilim ve anlatı üçlü bir ilişki içinde ilerler.

Anahtar Kelimler: Derviş Zaim Sineması, Sinema ve Mekân Çalıșmaları, Sinemasal Manzaralar.

\footnotetext{
* Bu çalışma Galatasaray Üniversitesi Sosyal Bilimler Enstitüsü'ne 2016 yılında sunulan, Prof. Dr. Nilgün TUTAL CHEVIRON danışmanlığındaki “Derviş Zaim: Bir Mekân Sineması'na Doğru” başıklı doktora tezinden türetilmiştir.
} 
Article Derived From Thesis

\title{
Space As A Platform of Narration In The Cinema of Derviş Zaim: The Relationship Between Space, Narration, and Cinematic Tension
}

\author{
Aydın Çam (Asst. Prof. Dr.) \\ Çukurova University Faculty of Communication \\ aydinaksu@gmail.com
}

Date Received: 04.01.2018

Date Accepted: 12.06 .2018

Date Published: 30.07.2018

\begin{abstract}
In this study, the cinematic spaces in the films of Derviş Zaim are examined as a stage on which events, facts and characters exist and as a platform on which cinematic action occurs. In the study, Derviş Zaim's filmography is analysed by textual and contextual methods. For this, each film of the director is deconstructed on the basis of its space plans. Quantitative data obtained from this work of deconstruction is presented, where appropriate, in charts, graphs and images. This data served as basis for contextual analysis. Moreover, interviews conducted with the director are included to the study through content analysis. In the study, firstly cinematic spaces are examined as elements of the director's cinematography via textual analysis. Secondly, it analysed how the director created cinematic tension between different types of spaces -categorized as interior, exterior, and in-between spaces through editing/montage while transforming the cinematic meaning.

The main results of this study, considering Derviş Zaim cinema in terms of cinematic spaces, would be summarized as follows: The space in Derviş Zaim cinema is used as the essential element of the film action, as the platform of the narration correspondingly action of the narration. The cinematic narration is enriched by jumps between interior and exterior spaces and the space not only constitutes a platform for the story, but also is used to create a new narration itself, to build the cinematic tension. The director transfers the tension between interior and exterior spaces to the tension of the story. While the tension becomes an element that merges spaces, the space serves as a platform for both the tension and narration. The space, the tension and the narration are developed in a triple relationship.
\end{abstract}

Keywords: The Cinema of Derviş Zaim, Cinema and Space Studies, Cinematic Landscapes. 


\section{Giriş}

“Titorelli'nin Albatros adlı öyküsünde, eksen karakter farklı, uzak ve ilgisiz mekânlara bir adımda geçebiliyordu. Geçebiliyordu çünkü Titorelli, haritaların, ansiklopedilerin, cartların curtların birbirleriyle ilgisiz gibi gösterdiği mekânları, yan yana, iç içe geçirmekten kaçınmamıștı. Teknik eski bir teknikti ama usturuplu kullanılırsa kampüsteki bağlantıları, ilişkileri, ilişkisizlikleri çok daha kapsamlı, çok daha derin olarak verme olanağını sağlıyordu. Bu teknik sayesinde cennetler ve cehennemler yan yana getirilebilir; üst üste bindirilir, toplamalar, çıkarmalar yapılabilirdi" (Zaim, 1995, 12).

Ares Harikalar Diyarında (1995) adlı ilk romanıla 1992'de Yunus Nadi Roman Armağanı'nı kazanır Derviş Zaim. Henüz yirmili yaşlarının sonundaki genç bir yazardır; lisans ve lisansüstü öğrenimini yeni tamamlamıştır ve Tabutta Rövaşata'yı (1996) gerçekleştirmesine epey vardır. Ancak, anlaşılan odur ki ilk uzun metraj filmden çok önce, sinemanın farklı mekânları bir araya getirerek hayali mekânlar oluşturma potansiyelinin, sinemasal mekânla film devinimi ilișkisinin ve sinemasal mekânların fizikî mekânda süregiden eylemi açığa çıkarma gücünün ayırdındadır. Yönetmenin mekânla kurduğu ilişkinin, çocukluğundan itibaren sıra dışı olduğunu söyleyebiliriz aslında. Doğduğu ve çocukluğunu geçirdiği kenti, Limasol'u 1974'te bir daha geri dönmemek üzere terk etmiştir. Limasol'daki çocukluğuna dair, bu çalışmanın bağlamıyla ilintili iki anısını biliyoruz. Birincisi televizyonla ilgili: Henüz Türkçe televizyon yayınlarının gerçekleștirilmediği bir coğrafyada, hiç anlamadığı bir dilde yapılan (Rumca) yayınları hayranlıkla izlediğini ifade ediyor. Televizyonun, bir mekânı başka bir mekânın içine taşımasını, onu yeniden var etmesini büyüleyici buluyor (Zaim, 13 Ocak 2016). İkinci anısı ise tam da Limasol'u terk ettikleri sırada yaşadıklarıyla ilgili. Kıbrıs'ta 20 Temmuz 1974'te başlayan yoğun Rum saldırıları sırasında, henüz on yaşında olan Derviş Zaim ve ailesi evlerinin bodrum katında saklanmaktadır: 'Lefkoşa'dan 'Teslim olun!' emri geldiğinde beyaz bayrak asılmasına rağmen ateş hattına girmemek için caddeden karşıya geçmek yerine, Zaim'in dedesinin bulduğu bir balyozla komșu evlerin duvarını dele dele bir mahalleyi geçerek hastanenin avlusuna sığınırlar" (aktaran Kırel ve Duyal, 2011, 7). Aile Limasol'u sonsuza dek terk edip Magosa'ya yerleșecek, lise öğreniminin sonuna kadar Magosa'da yaşayan Derviş Zaim ise bu kez anakaraya, İstanbul'a göç edecektir. Yönetmen, bu ikinci göçün de yaşamı üzerinde önemli etkisi olduğunu düşünmektedir: Ufuk çizgisiyle sonlanan bir coğrafyadan, ufuk çizgisinin hiç var olmadığı bir coğrafyaya taşınmak kendisi için sarsıcıdır (Zaim, 13 Ocak 2016). Henüz çocukken yaşanan, mekâna dair sıra dıșı deneyimler bunlar kuşkusuz. Televizyon ile dolayımlanmış bir mekân, öznenin mekânı aşıp geçme deneyimi ve mekâna bakışı topyekûn değiştiren bir göç...

Derviş Zaim'e göre "yönetmenlik denilen mefhum" biraz da zamanı ve mekânı biçimlendirmektir: "Yönetmene sonsuz bir zaman ve mekân verilmiştir ve bir uzun metraj filmin sınırları içinde onları istediği forma gelene kadar tıraşlamaktadır" (Zaim'den aktaran Bozdemir, 2008, 18-19). Ancak yönetmenin mekânı biçimlendirmesi kadar mekânın da onu biçimlendirmesi söz konusudur; yani mekânla yönetmen arasında yoğun bir etkileşim vardır. "Filmleri yaparken hoşuma giden taraflardan biri, kimsecikler yokken, yalnızken mekânlara gidip dolaşmak," der Derviş Zaim':

“Çekimlere başlamadan ya da set esnasında, meselâ sabahleyin, ekip olmadan mekânları dolaşırım. Mekânla konuşmaya, diyalog kurmaya çalışırım, mekânı koklarım, ortamın beni koklamasına çalışırım. Bu mekânı nasıl tıraşlayabilirim, buradan benim istediğim 
zamansal ritim çıkar mı, mekân bana nasıl bir zaman ritmi sunuyor diye bakarım. Bir şey ötekini çağırır; mekânı koklarsanız bazen o da size zamanı dikte eder, fısıldar" (Zaim'den aktaran Deniz, 2011, 103-104).

Bir filmin tasarlandığı ve bu tasarının gerçeklik kazandığı süreçte, filmin mekânlarıyla ilgili çalışmalar Derviş Zaim için bütün tasarım ve yaratım sürecinin önemli öğelerindendir. Yönetmen, sinema yapmanın en büyük keyiflerinin senaryo yazmak ve mekân aramak olduğunu, kendisinde ise bu iki durumun iç içe geçtiğini ifade etmektedir: "Mekân ararken senaryo yazmaya devam ederim ya da senaryo biter ama mekânları bulmadıkça o senaryoya tamam demem, tamamen senkronize gelişir bu ikisi" (Zaim, 2004, 42). Dahası, Derviş Zaim'in filmin senaryosunu, hatta çekimlerini tamamladığı ve gösterime soktuğu ve ancak mekânla etkileşimini sonlandıramadığı da olmuştur. Örneğin, Çamur (2003) filminin mekânlarından biri olan Tuz Gölü, yönetmeni öylesine derinden etkiler ki yönetmen geriye dönme ihtiyacı hisseder; Nokta (2008) bu ihtiyaçtan doğar.

Derviş Zaim'in gerek filmografisine gerekse sinemayla ilgili görüşlerine bakıldığında mekâna özel bir önem atfettiği görülmektedir. Yönetmenin sinemasında mekân, içerik açısından önemli ve belirleyici bir temalar kümesi oluşturur: Mekânın sınırlandırılması, düzenlenmesi, kontrol altına alınması; mekânın öznelere yasaklanması, öznenin mekân üzerindeki hareketlerinin denetlenmesi, bölünmüş coğrafyada bir alandan diğerine geçerken özneyi denetleyen bir iktidar olgusu gibi temalar yönetmenin her filminde görülür. Diğer yandan Derviş Zaim sineması söz konusu olduğunda, mekânla ilintili temaların içeriği belirlemesi - içeriği oluşturması kadar, mekânın film üretim sürecinin temel yapıtaşlarından biri haline geldiği de görülmektedir. Mekânın senaryoya bağlı olarak belirlenmesinden çok, doğrudan mekâna bağlı, mekânla etkileșimli bir senaryonun yazılması; mekânın filmin karakterlerinden biri haline gelecek kadar ön planda olması; mekânın sinemasal anlam alanının temel öğelerinden biri olarak kullanılması ve mekâna dayanan bir sinema kuramı oluşturma çabalarının ipuçlarının görülmesi adeta bir mekân sinemasına işaret etmektedir. Pekiyi bu bağlamda, yönetmenin mekân kullanım etkinlikleri hakkında ne söylenebilir? Derviş Zaim'in sinemasal mekânları filmin anlam üretimi bağlamında nasıl değerlendirilebilir? Yönetmenin filmografisi mekân bağlamında biçimsel ve bağlamsal olarak çözümlendiğinde ona özgü bir sinemasal mekân kullanımından söz etmek mümkün olabilir mi?

\section{1. Çalışmanın Amacı, Temel Varsayımı ve Yöntemi}

Derviş Zaim filmlerindeki sinemasal mekânları anlatının platformu olarak kullanılması bağlamında çözümlemek bu çalışmanın temel amacıdır. Çalışmanın temel varsayımıysa, yönetmenin mekâna yaklaşımının kurmaca sinemanın genel yapısına benzediği ancak ara mekânları kullanım biçimiyle bunu aşmakta olduğudur. Bu amaca ve varsayıma yönelik çözümlemeyi gerçekleştirmek içinse öncelikle daha senaryo yazım aşamasında karşımıza çıkan, mekânın sinema sanatındaki en temel ayrımına göre bir değerlendirme yapılarak yönetmenin filmografisi iç ve dış mekân bağlamında incelenecektir. Sahnenin zamana bağlı olarak gün ve gece ölçütlerine göre değerlendirilmesiyle birlikte bu ayrım, film üretiminin planlanmasının temel ölçütlerinden biridir. Bu ayrımla birlikte yönetmen ve/veya yapımcı, oyuncuların rollere göre dağılımı, ulaşım, konaklama, bütçe ve benzeri diğer ölçütleri de göz önünde bulundurarak çekim takvimini oluşturur. Çekim öncesi çalışmaların önemli bir ayağı olan çekim takviminin planlanması film üretiminin pratik öğeleri göz 
önünde bulundurulduğunda çoğunlukla mekâna bağlı olarak yapılmaktadır. Bunun için senaryo sahnelerine ayrılır, sıralanır ve senaryodaki sahnelerin geçtiği tüm mekânlar iç ve dış mekânlar olarak ayrılarak listelenir. Yine buna bağlı olarak, bir mekânda geçen tüm sahneler de listelenir ve o mekândaki çekimlerin kaç iş gününe yayılacağı belirlenir. Set bir kez kurulduğunda o mekânda geçen bütün sahnelerin çekiminin gerçekleştirilmesi öncelikli hedeftir. Mekânın planlanması film üretiminin temel öğelerinden biridir ve öncelikli olarak gözetilmektedir. Mekânın planlanırken iç ve $d ı s ̧$ olarak ayrılmasının basit bir mantığı vardır: Çekim sırasında, özellikle ıșık gibi, seti etkileyen öğelerin denetlenebilir olup olmamasına göre bu ayrımın yapıldı̆̆ı söylenebilir. Değişen hava koşullarına göre çekimin gerçekleştirilip gerçekleştirilemeyeceği ya da setin aydınlatılması için gün ışığından yararlanılıp yararlanılamayacağı yönetmenin ve/veya yapımcının temel kaygısıdır. Genellikle ve çoğunlukla denetlemesi pek de kolay olmayan dış mekân şartlarındaki çekimlerin bitirilip sonra pekâlâ çok daha kolay kontrol edilebilen iç mekân çekimlerine geçilmesi yönünde bir planlama yapılmaktadır. Ama salt bu yapım planlamasını aşacak bir biçimde, anlatıya bir platform oluşturması bakımından da Derviş Zaim sinemasında mekânın iç ve dış olarak ayrılması önemlidir. Çünkü yönetmen, bu iki mekân arasındaki geçişlerle ya da bu iki sınıflandırmaya dâhil edilemeyecek ara mekânlarla gerilimi kurar. Dolayısıyla bu çalışmada öncelikle yönetmenin filmlerindeki mekânlar bu bakımdan irdelenecek ve sonra da bu iki genel mekân sınıflandırmasının film kurgusu/montajı sırasında kullanımıyla üretilen ara mekân(lar) ve anlam(lar) değerlendirilecektir.

Gerek biçimsel gerekse bağlamsal film çözümle yöntemleri bağlamında (Ryan \& Lenos, 2012; Pramaggiore \& Wallis, 2008; Barsam \& Monahan, 2010; Corrigan \& White, 2012) bir filmin planlarına ayrılarak çözümlenmesi önemli bir araştırma yöntemidir. David Bordwell ve Kristin Thompson da, Film Sanatı - Bir Giriş (2011) adlı çalışmalarında bazı araştırmacıların filmlerin ortalama çekim uzunluklarını hesaplayarak film ritmi üzerinde inceleme yaptıklarını belirtirler ki Bordwell de bizatihi bu araștırmacılardan biridir. The Way Hollywood Tells it: Story and Style in Modern Movies (2006) adlı çalışmasında başlangıcından bugüne değin, giderek hızlanan Hollywood sinemasını değerlendirmek için bunu yapmıştır. Bordwell ve ondan ilham alan araştırmacılar yaptıkları çalışmalarda bir filmi kurgu/ montaj işlemini bir bakıma tersine çevirerek planlarına ayırmışlar, bu planları sınıflandırmışlar, uzunluklarını, tekrarlama sıklıklarını vb. ölçmüşler ve niceliksel veri elde etmişlerdir. Yapılan bu çalışmalarla, Hollywood sinemasının tarihi boyunca plan uzunluklarında yaşanan dönüşümler -örneğin giderek hızlanan diyalog planları-; Hollywood sinemasıyla Avrupa sinemasının plan uzunlukları bakımından farklılıkları; plan uzunluklarının yönetmenin estetik yaklaşımıyla bağıntısı soruşturulmuştur ve soruşturulmaya da devam edilmektedir. Bu çalışmalarla sadece bir filmin en uzun ya da en kısa planları belirlenmez ya da ortalama veya filmin en çok tekrar eden plan uzunluğu saptanmaz; kaldı ki bu veriler bile bir film hakkında çok şey söyleyebilir. Böylesi bir biçimsel çözümleme genişletilerek çekim ölçekleri, çekim açıları, kamera hareketleri ve kurgu/montaj biçemiyle ilgili de niceliksel veri elde edilebilir; bu veri örneğin sahnelemenin ve sahneleme aracılığıla anlam üretiminin değerlendirilmesi için kullanılabilir (Elsaesser ve Buckland, 2002, 101116). Bugün, filmlerin planlarına ayrılmasıyla gerçekleştirilen çalışmalar yaygın bir şekilde yapılmaktadır. Örneğin Yuri Tsivian'ın girişimiyle kurulan küresel sayısal ağ tabanlı Cinemetrics örgütlenmesi (http://www.cinemetrics.lv), filmlerin biçimsel 
çözümleme amacıyla planlarına ayrılması için bir platform sağlamaktadır. Açık erişimli örgütlenme, kullanıcılarına çevrimiçi ortamda, bir yazılım aracılığıyla, diledikleri filmi planlarına ayırma olanağı sağlamaktadır. Bu çalışma kapsamında gerçekleştirilen biçimsel çözümlemeyle, Derviş Zaim sinemasında mekân kullanımının genel yapısı belirlenmeye çalışılmıştır. Bu biçimde elde edilen veriyle, iç ve dış mekân geçişleri saptanmaya ve bu geçişlerin sinemasal anlatıyla ilişkisi çözümlenmeye çalışılmıştır.

Bordwell (2006), Elsaesser ve Buckland (2002) ve Tsivian'ın çalışmalarından hareketle, bu çalışma kapsamında Derviş Zaim'in filmografisi ve sinematografisi biçimsel çözümleme yöntemiyle değerlendirilmiştir. Bunun için, Tabutta Rövaşata (1996), Fillerve Çimen (2001), Çamur (2003), Cenneti Beklerken (2007), Nokta (2008), Gölgeler ve Suretler (2011), Devir (2012) ve Balık (2014) biçimsel çözümlemeye tabi tutulmuştur. Çalışmanın gerçekleştirildiği dönemde, Derviş Zaim'in tamamlamadığı ve henüz gösterime girmeyen Rüya (2016) adlı filmi, off-line kurgu işlemlerinin yapıldığı GeniusPark (Ortaköy/İstanbul) stüdyosunda izlenmiş, ne var ki henüz son halini almamış bu film biçimsel çözümlemeye dâhil edilmemiştir. Bununla birlikte, Derviş Zaim'in filmlerinin planlarına ayrılması için pratik gerekçelerle, Cinemetrics'in çevrimiçi platformu yerine Adobe Premiere Pro CS5² profesyonel kurgu programı tercih edilmiştir. Adobe Premiere Pro CS5, bir filmi planlarına ayırmak için Cinemetrics'in sağlayamadığı, çok daha nitelikli araçlara sahiptir ve bu sayede çok daha hassas bir biçimde niceliksel veriye ulaşmak mümkün olmaktadır. Örneğin, Cinemetrics iki planı kabaca saniye bazında birbirinden ayırırken Adobe Premiere Pro CS5 bunu saniyede 24 kare esasına göre ve kare bazında gerçekleştirmektedir. Planların üst üste bindirilerek kurgulandığı/montajlandığı kimi durumlarda, iki plan Adobe Premiere Pro CS5 programıla kolaylıkla ayrılabilmektedir. Üstelik filmin planlarına ayrılması işlemi Adobe Premiere Pro CS5 aracılığıyla bir kez yapıldığında, kesilen planları defalarca başka bağlamlarda bir araya getirerek niceliksel veriye ulaşmak ve/veya görselleştirmek mümkündür. Bununla birlikte, bahsi geçen kuramsal çerçevede ve Cinemetrics aracılığıyla gerçekleştirilen çalışmalarda bir film bütün planlarına ayrılırken -bu, örneğin bir Hollywood filmi için ortalama 2.500 3.000 plan demektir-, bu çalışma kapsamında, Derviş Zaim'in filmleri, çalışmanın merkezinde duran sinemasal mekânlar temel alınarak planlarına ayrılmıştır. Filmin mekân bağlamında planlarına ayrılması, filmdeki her bir mekân planının kesilmesi anlamına gelir. Yani, filmde sinemasal eyleme platform oluşturan bir mekân değișip de eylem yeni bir mekân üzerinde devinmeye başladığı anda film kesilerek planlarına ayrılır. Film, bu yöntemle planlarına ayrıldığında, sınıflandırmak ve niceliksel veriye ulaşmak artık mümkündür. $\mathrm{Bu}$ çalışmada gerçekleştirilen çözümleme kapsamında, Bulgular ve değerlendirmeler: Derviş Zaim Sinemasında İç, Dış ve Ara Mekânlar başlıklı bölümde yönetmenin sinematografisinin öğesi olarak sinemasal mekânlar incelenmiștir. Bu bölüme ait, Sinemasal Gerilimin Yaratılmasında Kurgu ve Mekân İlişkisi başlıklı ayrımdaysa yönetmenin iç, dış ve ara mekânlar olarak sınıflandırılan farklı mekân tipleri arasında, kurgunun/montajın olanaklarıyla devinerek bir yandan sinemasal gerilimi yaratırken diğer yandan sinemasal anlamı nasıl dönüştürdüğü biçimsel çözümlemeyle değerlendirilmiştir. Bununla birlikte yönetmenle gerçekleştirilen söyleşi ve görüşmeler içerik çözümlemesiyle nitel verilere dönüştürülerek çalıșmaya dâhil edilmiştir. Her iki ayrımda gerçekleştirilen biçimsel çözümlemeler, mekânın sinemasal anlatıların bir öğesi olarak somut bir biçimde arka alanda yer aldığı - anlatıya bir platform oluşturduğu, dolayısıyla 
böyle bir çözümlemede, bir eğretilemeye dâhi göndermede bulunmadan, sinemasal mekânın öncelikle somut bir değerlendirmeye tabi tutulması gerektiği öncülüne dayanmaktadır.

\section{Bulgular ve Değerlendirmeler: Derviş Zaim Sinemasında İç, Dış ve Ara Mekânlar}

"Sinemada sahneye koyma başlangıç noktasıdır ve sinemasal anlatımın özgün yapısı buradan doğar. Senaryoyu ve kurguyu belirleyen yalnız konu değildir, aynı zamanda sahneye koymadır da, daha doğrusu dramatik aksiyonun zaman ve mekân içinde oyuncular tarafından canlandırılma şeklidir" (Eisenstein, 2006, 20).

İlk elden fiziksel varoluşun platformu olarak nitelendirilebilecek mekân, Lumière Kardeşler'den bu yana pek çok işlevi üstlenerek sinema sanatına dâhil olmaktadır. Mekân, sinemasal eylemin sahnesidir en bașta: Olaylar, olgular ve karakterler mekânda yer alır ve sinemasal eylem mekân üzerinde devinir. Ve yine mekân, bizatihi fiziksel bir gerçeklik olarak sinema sanatıyla bir araya gelmiştir. "Doğanın stilize edilmesi -izlenimci ya da dışavurumcu- bir filmin sanat yapıtına dönüşmesinin koşuludur. Zira bir coğrafya dersi kitabı değil, insanın yazgısının ifadesi olmak isteyen sinemada nötr gerçeklik olarak 'doğa' yoktur” (Balázs, 2013, 85). Derviş Zaim'in filmografisi Balázs'ın bu önermesi bağlamında değerlendirildiğinde, ister kentte isterse kırda-doğada yer alsın, öncelikle mekânın stilize edilerek sinemasal eyleme bir platform oluşturmak amacıyla kullanıldığı görülür. Ama bu noktada, yönetmenin sinemasal manzaraları anlatıya bir platform oluşturmak için nasıl kullandığını yorumlanmadan önce sinemasal manzara kavramsallaștırmasına bakmak gerekir. Sinemasal manzara (cinematic landscape), sinema ve mekân kuramclarından Anton Escher'in (2006) üzerinde durduğu bir kavramdır. Sinemasal manzara -ve sinemasal manzaraların kentsel mekânlarda görüldügü haliyle kent manzaraları (cityscapes)fizikî dünyanın nesnel bir parçası olan ve dünya üzerinde bir yer işgal eden mekânın kültürel ya da kurgusal öğelerle iç içe geçerek kadraja alınmasıdır. Resim, edebiyat, fotoğraf ya da kartpostallarda olduğu gibi, sinemada da aslında ilk kez görülen bir manzara yoktur. İzleyici manzarayı görmezden çok önce alımlamış ve öznel izlenimleriyle birleștirerek imgesel bir tezahürünü yaratmıştır zaten. Bir sinemasal manzaranın izleyicinin maddî dünyada gördüğünü gerçekçi bir biçimde yansıtıp yansıtmadığı değil, izleyicinin/alımlayıcının gördüğü temsile güvenip güvenmediği ve bu manzarayı içselleștirip içselleștirmediği önemlidir. Escher'in bu önermesi bizi gerçeklik ve temsil üzerine bir soruşturmaya davet eder. Diğer yandan bu önermeye bağlı olarak, bir kez daha her sinemasal imge gibi, mekânın da tarihsel, toplumsal ve kültürel bağları olduğu ve bu bağlar olmaksızın mekânın sinemasal temsilini anlamlandırmanın eksik kalacağı söylenebilir.

Çalışmalarında temel olarak sinema ve tiyatronun manzara ve dolayısıyla mekânla ilişkisini, tiyatro/sahne eğretilemesinin sinemaya nasıl aktarılabileceğini ve yine bunun mekânla ilişkisini ve son olarak mekânın/manzaranın sinema ve video anlatısıyla etkileşimini merkeze alan Chris Lukinbeal'a (2005) göre ise manzaralar sinemasal mekânların temel biçimidir. Tarihsel bağlamda sinemasal olaylara anlam kazandırır ve anlatıya bir konum sağlarlar. Manzaralar öykünün tutunacakları alanlar, dramatik anlatının ilerleyebileceği ortamlardır. Bununla birlikte manzaralar, tıpkı sinema sanatının kendisi gibi görsel ve algısal açılardan toplumsal olarak inşa edilir; manzaralara yaklaşımımız ve anlayıșımız kültürel, davranışsal ve deneyimsel olarak biçimlenmiştir. Manzaralar öncelikle tiyatrodaki sahne gibi işlev görür: Tiyatro sahnesinin düzenlendiği gibi toplumsal ve sanatsal bazı kurallara tabidir; bir tiyatro 
sahnesi gibi tasarlanır, düzenlenir ve izleyiciye tıpkı bir tiyatro sahnesindeymiş gibi, sahnenin merkezine konumlanmasına olanak sağlar. Sinema ve tiyatronun ilişki ve benzerliğinin sinemasal mekânın tasarlanması ve örgütlenmesine sızan etkileri bunlarla da kalmaz; sinemasal mekân da tıpkı tiyatro sahnesi gibi bir gösteriye alan oluşturur, kültürel üretim burada gerçekleşir ve iktidar ilişkileriyle dolayımlanır (Lukinbeal, 2005, 4). Tüm bunlar sinemasal mekâna dair bütünlüklü bir çözümlemenin parçalarıdır. Ancak bu çalışmada irdelenen konu, yani anlatının platformu olarak mekân, temel olarak çok daha yalın ve teknik bir konudur. Bununla kastedilen, özetle sinemanın genel üretim yapısı içinde çekim ölçekleri, planları ve ilk elden izleyicinin mekânda kaybolmamasını sağlayan 180 derece kuralı gibi öğe ve tekniklerle izleyicinin sinemasal mekâna tutunmasının sağlanmasıdır. Derviş Zaim sineması söz konusu olduğunda ise görüntü düzenlemesinin ve sinematografinin mekâna dair bu temel ilkelerine sadakatle uyulmasının yanı sıra, mekânın film devinimine platform oluşturarak ve onunla iç içe geçerek anlatıyı taşıması, güçlendirmesi ve yeni anlamlar-duygular oluşturacak biçimde yeniden düzenlenmesinden bahsedebiliriz.

Derviş Zaim'in filmografisi iç, dış ve ara olarak sınıflandırılabilecek çeşitli mekânları kapsar. İç mekânlar olarak evler, konaklar, bekâr odaları, tuvaletler ya da otomobiller gibi özel alanlar kullanılmaktadır; ancak göreceli olarak yoğun bir kullanım olduğu söylenemez. Özel alanların yerini kamusal alanlar ya da kamusal alanların bir biçimi olarak nitelendirebileceğimiz yer-olmayanlar ve/veya heterotopyalar almıştır. Kahvehaneler, hastaneler, eczaneler, kadın doğum klinikleri, revir, yatakhaneler, teneffüshaneler, karakollar, askerî cezaevleri ya da hapishaneler, askerî tesisler, atık su arıtma tesisleri, Milli İstihbarat Teşkilatı Binası, bakanlık binaları, üniversite binaları, nakkaşhane ve kervansaraylar gibi resmi ya da yarı resmi kurumlar, tam da Türkçede yaygın biçimde kullanıldığı anlamıyla kamusal alanlara ait iç mekânlar çoğunluktadır. Oteller, fabrikalar, hamamlar, restoranlar, müzeler, atölyeler, depolar, balık halleri, tamirhane, nalbur, berber, bakkal ya da pastane gibi dükkânlar, camiler ve türbeler gibi halka ait-sivil kamusal alanlara dair iç mekânlara da rastlanır. Bununla birlikte otomobiller, otobüsler, trenler ve yatlar gibi taşıtlar da mekân olarak kullanılmaktadır. Tablo 1, Şekil 1 ve Şekil 2'de yer aldığı gibi, yönetmenin filmografisine bakıldığında, 1996'da gerçekleştirdiği Tabutta Rövaşata'da iç ve dış mekânların hemen hemen aynı oranda kullanıldığı görülmektedir. Filmin giriş ve çıkış jenerikleri çıkarıldığında her iki mekânda geçen sahnelerin süresi neredeyse eşittir. İç mekânlara ayrılan süre yaklaşık olarak yüzde 42 iken, dış mekânlar film süresinin yüzde 52'sini kapsar (kalan yüzde 6 jeneriğe ayrılan kısımdır). Genellikle "İstanbul filmi" olarak tanımlanan, gerçekten de İstanbul manzaralarına yer veren bir film için aslında dikkat çekici oranda bir iç mekân kullanımından söz edilebilir. Buna karşın yine de dış mekânda geçen sahneler oransal olarak daha fazladır. Oysa 3 Kasım 1996'da Balıkesir'in Susurluk ilçesi yakınlarında gerçekleşen kazaya göndermede bulunarak 'devlet-siyaset-mafya' üçgenindeki derin ilişkileri irdeleyen, yönetmenin ikinci filmi Filler ve Çimen'de iç mekân kullanımıyla dış mekân kullanımı arasında belirgin bir fark görülmektedir. Filmin mekânları, anlatının merkezinde yer alan ve kapalı kapılar ardında gerçekleşen karanlık ilişkileri eğretiler bir biçimde ağırlıkla iç mekânlardır. Evler, büro, otel, Emniyet Müdürlüğü, Milli İstihbarat Teşkilatı Binası, bakanlık binası, hapishane ve hastanelerle; yine aynı ilişkilerin hâkim olduğu yatlar, balıkçı tekneleri, otomobiller, kamyonetler, otobüsler, ambulanslar ve diğer taşıtlar filmin iç mekânlarını oluşturur. Bu iç mekânlar, tüm filmin yüzde 60’ından fazlasına 
yayılırken, dış mekânlarsa yüzde 35 kadarını kapsar. Şekil 1 ve 2'de de belirtildiği üzere, Derviş Zaim'in tüm filmleri içinde bu, en yoğun iç mekân kullanımının görüldügü filmdir.

Hernekadar Fillerve Çimen' de görüldügü kadar, belirgin birfarkolmasa dayönetmenin üçüncü filmi Çamur'un da iç mekânlarda geçen sahnelerinin süresi dış mekânlarda geçen sahnelerin süresinden fazladır. Fizikî mekânıyla sinemasal mekânı arasında belirgin çelişkiler olan bu filmin, özellikle bu çelişkiler nedeniyle, kontrol edilebilir ve bir set olarak düzenlenebilir iç ve dış mekânlarda çekilmesi olağandır. Filmin yaklaşık kırk altı dakikası, yani jenerik de dâhil olmak üzere film süresinin yaklaşık yarısı iç mekânlarda geçer. Filmin fizikî mekânıyla sinemasal mekânı arasındaki çelişkileri ortadan kaldırmak için yönetmenin dikkate aldığı teknik gerekçeler nedeniyle bir sonraki filmi olan Cenneti Beklerken'de de sinemasal manzaralar kadar iç mekân görüntüleri filme hâkim olur. Bu, tekrar etmek gerekirse filmin gerçek(çi) liğini zedelememek amacıyla yönetmenin dikkate aldığı bir zorunluluktur. Esasen bir Kıbrıs filmi olan Çamur'un Kıbrıs'tan epey uzakta, Anadolu coğrafyasında çekilmek zorunda kalınması ve bir dönem filmi olan Cenneti Beklerken'in sinemasal zamanıyla gerçekleştirilme zamanı arasındaki birkaç yüzyıllık fark, yönetmenin kontrol edilmesi, denetlenmesi pek de kolay olmayan dış mekânlardan ziyade iç mekânlara yönelmesini bir bakıma zorunlu kılmıştır. Buna karşın, Cenneti Beklerken'de de, Çamur ya da Tabutta Rövaşata'da olduğu gibi, iç ve dış mekânlar arasında süre bakımından belirgin bir fark yoktur. Yaklaşık yedi dakikalık uzun açılış jeneriğiyle dikkat çeken bu filmin iç mekânları film süresinin yaklaşık yüzde 48'ine hâkimken dış mekânları da film süresinin yaklaşık yüzde 46'sında görülür. Yönetmenin bu ilk dört filmi arasında Filler ve Çimen'de iç mekân kullanımının yoğunluğu dikkat çekerken diğer üç filmde iç ve dış mekânlar arasında dengeli bir dağılım olduğunu söylemek mümkündür. Oysa yönetmenin filmografisinin geri kalan dört filminde bu dağılım diș mekânlar lehine belirgin bir biçimde bozulacak ve Derviş Zaim filmleri adeta açık alanları, manzaraları ve gökyüzünü kendine arka alan edinecektir.

Derviş Zaim'in filmografisinin dış mekânlarını sinemasal manzaralar ve kent manzaraları oluşturur. İstanbul Boğazı, Fatih Sultan Mehmet Köprüsü, Eski ve Yeni Galata Köprüsü, Rumeli Hisarı, Tarlabaşı Bulvarı, Sultanahmet Meydanı, Salacak Sahili, Galata Kulesi, Tuz Gölü, askerî tesisler, sınırlar, mermer ocakları, sanayi siteleri, fabrikalar, havaalanları, marinalar, iskeleler, stadyumlar, menziller, kervansaraylar, okul bahçeleri, çay bahçeleri, parklar, camiler, türbeler, mezarlıklar, bahçeler, tarlalar, köy meydanları, kırlar, otlaklar, göletler ve göller film anlatısına platform sağlayan yerlerdir. Bununla birlikte sandallar, otomobiller, kamyonetler, otobüsler ve diğer taşıtlar da filmlerde kullanılan dış mekânlar olarak nitelenebilir. Dış mekânlardaki çeşitlilik dikkat çekicidir ve tüm bu mekânlar gerçek olduğu kadar, zaman zaman gerçeküstü bir biçimde film anlatısının platformunu oluşturur. Tablo 1, Şekil 1 ve 2'de görüldüğü gibi, yönetmenin 2008 yılında gerçekleştirdiği Nokta'yla birlikte dıș mekân kullanımında ciddi bir dönüșüm yașanmıștır. Mekân kullanımı açısından hâlihazırda sıra dışı bir yerde duran Nokta bütünüyle dış mekânda gerçekleştirilmiştir. Film boyunca kamera, tıpkı filmin karakterleri gibi, tek bir planda dâhi iç mekâna girmez. Filme, adeta sonsuzluğu imleyen Tuz Gölü ve gökyüzü arka alan oluşturur. Tuz Gölü, anlatı için, gücünü aldığı tasavvufî yaklaşıma uygun bir biçimde yekpare bir dış mekân, yazılmayı bekleyen bir sayfa, bir platform oluşturur. Bu beyazlık, giriş jeneriğiyle birlikte filmin neredeyse tamamına hâkimdir; 
yaklaşık üç dakikalık final jeneriği haricinde film, dış mekânda ve beyazlık üzerinde geçer. Bu açıdan sinema tarihinin nadide örneklerinden birini oluşturur.

Tablo 1: Derviș Zaim Filmografisinin Zaman/Mekân Planlaması

\begin{tabular}{|l|l|l|l|l|}
\hline \multirow{2}{*}{ FiLM } & \multicolumn{4}{l}{ SÜRE* } \\
\cline { 2 - 5 } & IÇ MEKÂN & DIŞ MEKÂN & JENERiK & TOPLAM \\
\hline Tabutta Rövaşata (1996) & $0: 35: 32$ & $0: 38: 44$ & $0: 03: 21$ & $1: 17: 37$ \\
\hline Filler ve Çimen (2001) & $1: 08: 37$ & $0: 36: 36$ & $0: 03: 48$ & $1: 49: 01$ \\
\hline Çamur (2003) & $0: 46: 06$ & $0: 42: 49$ & $0: 05: 39$ & $1: 34: 34$ \\
\hline Cenneti Beklerken (2007) & $0: 50: 16$ & $0: 47: 38$ & $0: 06: 39$ & $1: 44: 33$ \\
\hline Nokta (2008) & $0: 00: 00$ & $1: 05: 57$ & $0: 04: 39$ & $1: 10: 36$ \\
\hline Gölgeler ve Suretler (2011) & $0: 48: 17$ & $0: 58: 31$ & $0: 05: 21$ & $1: 52: 09$ \\
\hline Devir (2012) & $0: 18: 22$ & $0: 51: 17$ & $0: 03: 22$ & $1: 13: 01$ \\
\hline Balık (2014) & $0: 20: 11$ & $0: 59: 37$ & $0: 03: 26$ & $1: 23: 14$ \\
\hline
\end{tabular}

Süre, saat:dakika:saniye formatında ifade edilmektedir.

2011 yılında gerçekleștirilen ve Kıbrıs'taki çatışmaları konu alan Gölgeler ve Suretler, her ne kadar filmin sinemasal zamanıyla gerçekleştirme zamanı arasında birkaç yüzyıl yerine birkaç on yıllık bir fark bulunsa da, Cenneti Beklerken gibi bir dönem filmi olmasına karşın, yine Kıbrıs'ı sinemasal mekân olarak alan Çamur'un aksine iç mekân yerine çoğunlukla dış mekânda filme alınmıştır. Filmde Kıbrıs'ın kırsal alanının manzaraları uzun dış mekân sekanslarıyla perdeye yansıtılır. Derviş Zaim filmografisinin en uzun filmi olan Gölgeler ve Suretler'in yaklaşık bir saatlik dış mekân planları tüm filmin yaklaşık yüzde 55'ini oluşturur; filmin iç mekânlarıysa yine yaklaşık olarak tüm planların yüzde 42'si kadardır. Yönetmen, kapitalist tahakküm ilișkileri altında ezilen özne ve mekân, insan ve doğa ilişkisini irdelediği son iki filmi Devir ve Balık'ta da kamerasını belirgin bir biçimde dış mekâna, sinemasal manzaralara yöneltir. Bu filmler, içeriklerine son derece denk bir biçimde dış mekânların, sinemasal manzaraların filmleridir. Her iki filmin de en az yüzde 70'i dış mekânda geçer; özellikle Devir, uzun dış mekân sekanslarına sahiptir. Yine her iki filmde de geniş otlaklar, kırsal manzaralar, göller, göletler ve sazlıklar görülür. Yönetmen, kapitalist tahakküm ilișkileri altında dönüșen ve yıkıma uğrayan doğayı en saf haliyle çerçevelemeye çalıșır. Nokta'da sembolizmin bir öğesi olarak kullanılan diş mekân, burada yine sembolist öğelere platform oluşturmakla birlikte tüm gerçekliğiyle yer almaktadır. Her üç filmde de çerçevenin üst yarısını genellikle gökyüzü doldururken alt yarısı Nokta'da Tuz Gölü'nün sonsuz beyazlığıyla, Devir ve Balık'taysa kır ve göl manzaralarıyla bezenmektedir. Yönetmen, nasıl ki Filler ve Çimen'in karmaşık iktidar ilişkilerini iç mekânlarla ve onun üzerinde süregiden ilişki ağlarıyla aktarmışsa, bu iki filmde doğa ve ona bağlı kültürün yıkıma uğratılmasını dış mekânlarla ve dıș mekânda yer alan insan-doğa ilişkisiyle aktarmaya çalışmıştır. Devir ve Balık'ta setin ağırlıkla dış mekâna kurulması tesadüfî değildir; mekân film deviniminin kurucu öğesi, anlatının platformu olarak, anlatıya denk bir biçimde kullanılmaktadır. Bunlarla birlikte iç ve dış mekân geçişleriyle sinemasal anlatı zenginleştirilmekte ve aşağıda, Sinemasal Gerilimin Yaratılmasında Kurgu ve Mekân İliş̧isi başlıklı ayrımda, geniş bir biçimde irdelendiği gibi sadece sinemasal anlatıya platform oluşturmakla kalmayarak aynı zamanda sinemasal gerilimi vurgulamak için kullanılmaktadır. 


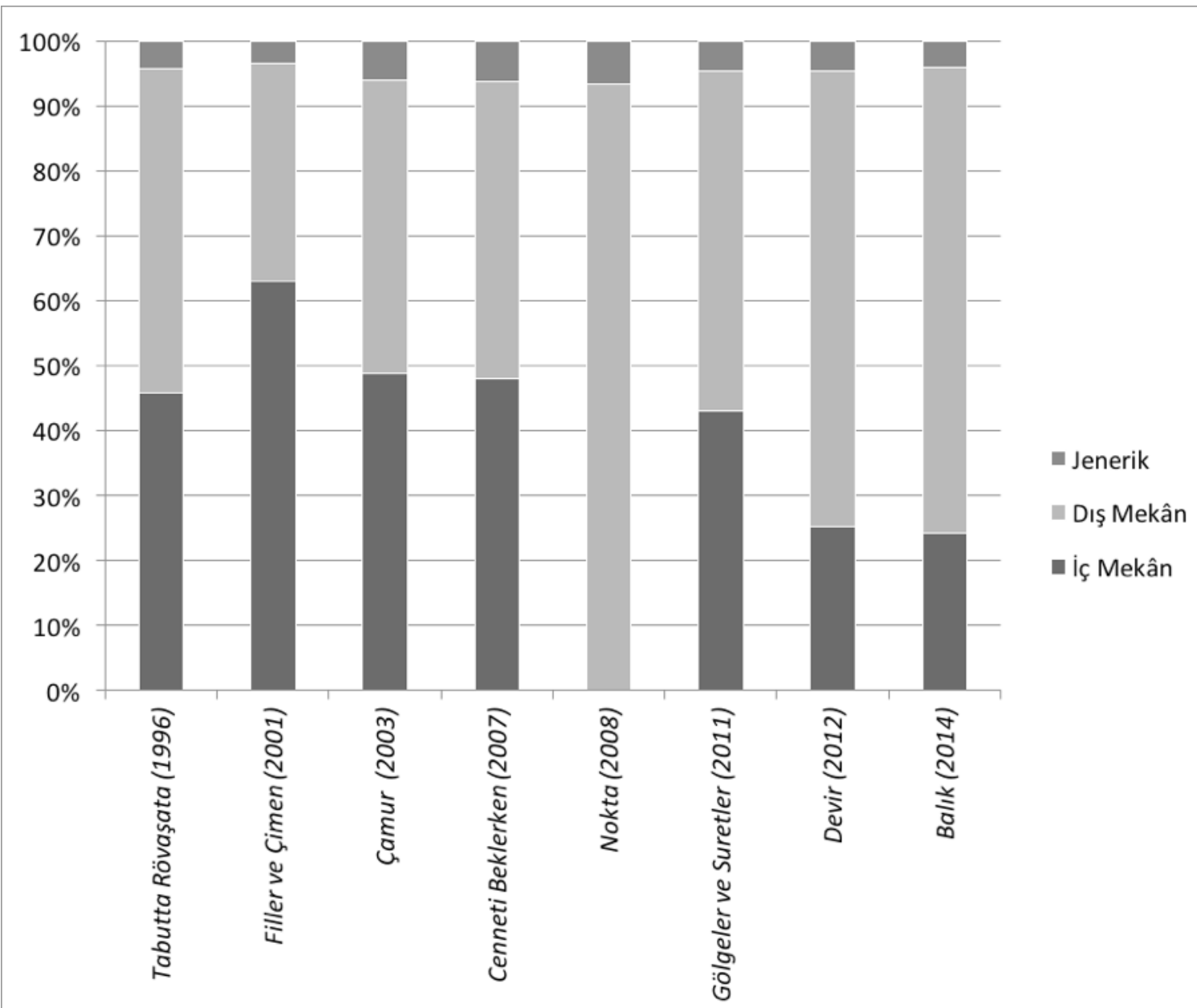

Şekil 1: Derviş Zaim Filmografisinde Sürenin Mekâna Göre Yüzdelik Dağılımı

Bu çalışma kapsamında iç mekânlara dâhil edilen ancak teknik olarak iç-dış mekân ayrımının tam olarakyapılamayacağı mekânlar da Derviş Zaim filmografisinde önemli bir yere sahiptir. Aydınlatma öğesi bakımından değerlendirildiğinde gün ışı̆̆ıyla aydınlatılabilen ve bu nedenle dış mekân sınıflandırmasına dâhil edebileceğimiz bu mekânlar, diğer yandan en azından kısmi olarak yapay aydınlatmayı da gerektirecek biçimde kapalıdır³; basit bir ifadeyle bu iç mekânlardan gökyüzünü görmek ilk elden pek de mümkün değildir. Tabutta Rövaşata'da Mahsun Süpertitiz'in (Ahmet Uğurlu) zaman zaman kullandığı bekâr odasıyla kahvehane arasında yer alan mekân; çoğu geceyi geçirdiği ve duvarları henüz örülmemiş inşaatın zemin katı; hayatın kendisi için bir yıkıma dönüștüğü gece, içinde uyumak zorunda kaldığı, sembolik anlamlarla yüklü top ara mekânlara örnektir. Filler ve Çimen'de Hızır Veli ve İlyas adlı karakterlerin yaşadığı sur kovuğu yine iyi bir ara mekân örneğidir. Çamur'da ara mekân olarak kuyu filmin merkezine yerleşir. Kıbrıs'taki askerliğinin son haftalarında gizemli bir hastalığa yakalandığı için konuşamayan Ali (Mustafa Uğurlu) nöbetlerdeki tüm zamanını bu ara mekânda geçirir. Yine aynı filmde Temel'in (Taner Birsel) restoranının çardaklı bölümü de bir ara mekândır. Cenneti Beklerken'de kervansarayların avluları ve bu avlularda yer alan çardaklar da tipik ara mekânlardır. Nokta'da birkaç taşıt planından başka ara mekân görülmez. Gölgeler ve Suretler'de Derviş Zaim'in ara mekân kullanımının en önemli örneği görülür. Așağıda açıklanacağı üzere, bu filmde yer alan bir ara mekân, bir kovuk, filmin en önemli gerilimlerinin mekânı olur. Devir'de görülen ara mekân bir ağıldır; yapının ön yüzü 
yoktur ve buradan bir avluya geçilmektedir. Avlu tamamen gün ışığıyla aydınlanırken, ağılın iç kısmı loştur; kısmen karanlıkta kalmaktadır. Balık'taysa balık hali ve kimya deposu ara mekânlar olarak sınıflandırılabilir. Her iki mekân da kısmen açık kısmen kapalı alanlardandır ve gün ışığıyla aydınlanır. Rüya'nın kritik mekânını olușturan ve Ashâb-ı Kehf - Yedi Uyurlar efsanesinin mekânı mağaraya göndermede bulunan cami de bir ara mekândır. Mimar Emre Arolat'ın mağara alegorisinden esinlenerek tasarladığı, İstanbul Büyükçekmece'deki Sancaklar Camisi'nin fizikî/gerçek mekânı olan bu yer, etrafi kısmen duvarlarla çevrili olmasına karşın salt güneş ışı̆̆ıyla aydınlanan bir ara mekândır. Filmin kavramsal arka alanında önemli bir konumda bulunan bu ara mekân, aynı zamanda film devinimi ve anlatısını da taşır.

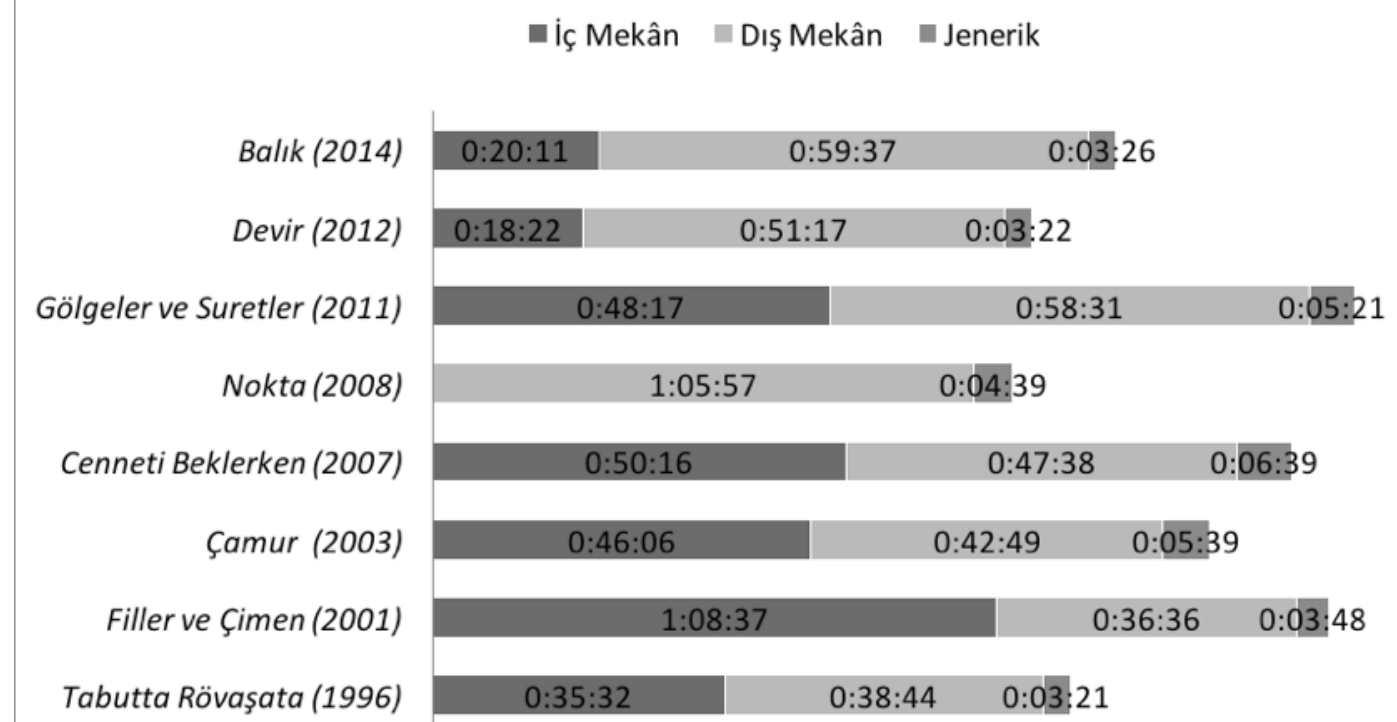

Şekil 2: Derviş Zaim Filmografisinde Sürenin Mekâna Göre Dağılımı

Bununla birlikte otomobiller, otobüsler, minibüsler, ambulanslar, banliyö treni, yatlar, tekneler ve sandallar gibi taşıtlar da ara mekânlar olarak sınıflandırılabilir. Bu taşıtlar aynı anda iç ve dış mekân olabilirler; üstelik bu mekânlarda çekim yapılırken çoğu zaman yapay aydınlatmaya da gerek duyulmaz. Geleneksel anlamıyla bir iç mekân, gün ışığı almayan ve yapay ışıkla aydınlatılan -ya da aydınlatılabilecek olanbir set iken taşıtlardan oluşan bu ara mekânlarda iç ve dış alanlar bir pencereyle ayrılabilmektedir; ki bu noktada bir muğlaklık söz konusudur. Dolayısıyla bu taşıtları iç ya da dış mekân ayrımı açısından kesin bir biçimde sınıflandırmak mümkün değildir. Ama bu çalışma kapsamında özellikle Tablo 1, Şekil 1, Şekil 2 ve Şekil 3 oluşturulurken taşıtlarda çekilen planlar, kameranın konumuna göre iç ve dış olarak ayrılmıştır: Kamera eğer aracın içindeyse çekimin iç mekânda yapıldığı, kamera eğer aracın dıșındaysa, yani aracı dışarıdan gösteriyorsa, çekimin dış mekânda yapıldığı varsayılmıştır. Ancak, tekrar etmek gerekirse, taşıtlar kesin bir iç ya da dış mekân karakteri göstermekten ziyade tam da ara mekânların muğlaklığına denk düşen yerlerdir. Yönetmen de taşıtları, anlatıya bir platform oluşturması bağlamında tıpkı ara mekânları değerlendirdiği gibi değerlendirmektedir. Taşıtlar açık bir biçimde ara mekân işlevi üstlenmektedir.

Derviş Zaim filmografisinde bir öznenin mekânla en yoğun ilişkisine tanıklık ettiğimiz Çamur'da, Ali'nin bütünleștiği ve film devinimi de taşıyan yer yine bir ara mekândır. Çamura ve kadim kültürlere kaynaklık eden kuyu aynı zamanda iç 
ve dış mekân arasında kalmış bir muğlaklık alanıdır. Ali, hastalığının ve kaderinin bilinmezliğiyle bu mekânda yüzleşir ve sinemasal gerilim kaynağını bilinmezlikten olduğu kadar mekândan da alır. Bir kuyu değil ama fizikî olarak kuyuya çok benzeyen bir kovuk, yönetmenin Kıbrıs'ı irdelediği diğer filmi Gölgeler ve Suretler'in de gerilimini taşır. Kovuklar, kovuğa benzeyen yapılar ya da küçük mağaralar Derviş Zaim'in filmografisinde önemli yeri olan ara mekânlardır. Gölgeler ve Suretler'de, köyleri (Yukarı Gyges) Rumlar tarafından boşaltılan Karagözcü Salih (Erol Refikoğlu) ve kızı Ruhsar (Hazar Ergüçlü), Aşağı Gyges köyünde yaşayan Salih'in kardeşi Veli'nin (Osman Alkaş) yanına sığınır. Ancak asıl niyetleri șehre gitmektir, bunun için bir sabah yola çıkarlar. Ne var ki bir süre sonra yolun Rum askerleri tarafından kesildiğini görür ve bulundukları aracı terk ederek kırların içine uzanan bir patikada kaçmaya başlarlar. Patika onları bir kovuğa götürür; kovuk önce Rum askerlerinden kaçışlarının yarattığı ilk gerilimin, sonra da baba-kızın ayrılmaya karar vermesiyle ortaya çıkan ikinci gerilim mekânı olur. Filler ve Çimen'de mafyanın işlediği cinayeti üstlenecek Hızır Veli ve İlyas doğal bir kovukta değil ama kimi zaman bir türbede, kimi zamansa Yenikapı surlarına açılmış olan bir oyukta, yine bir ara mekânda yaşamaktadır. Basit ve sıradan hayatlarının mekânıdır kovuk. Cenneti Beklerken'de, filmin neredeyse tüm gerilimi ara mekânlarla taşınır. Bu kez mağaralar, kovuklar, kervansarayların içinde bulunan ve dar avlulara bağlanan dehlizler, yani bir dizi ara mekân, film deviniminin sahnesidir. Eflatun (Serhat Tutumluer), hiç istemediği halde Şehzade Danyal'ı (Nihat İleri) bulmak ve öldürülmeden hemen önce bir portresini çizmek üzere çıtığı yolculukta, görevden azledilme ümidiyle kendini yaralamaya karar verir. Bunun için de bir kervan saldırısını fırsat bilerek bir mağaraya kaçar; gerek saldırıdan kaçmanın gerekse kendini yaralamanın geriliminin mekânı bu mağara olur. Daha sonraları konakladıkları kervansaraylarda ve şehzadenin hapsedildiği dehlizlerde benzer gerilimler benzer ara mekânlarda vuku bulacaktır. Bu noktada şu bulguyu dile getirebiliriz artık: Derviş Zaim filmografisinde iç ve diş mekân kullanımının özellikleri -iç ya da dış mekân kullanım süresinin ve oranının filmlere göre değişimi- öncelikle yönetmenin anlatısındaki değişime koşuttur. Yönetmenin doğaya dönüşüyle birlikte, kamera da -gayet doğaldır ki- dış mekâna çıkar. Bununla birlikte, aşağıdaki bölümde değerlendirileceği gibi, ara mekânlar iç ve dış mekânların süre ya da oranından bağımsız olarak, bu mekânlar arasındaki gidişgelişlerle de ortaya çıkmaktadır.

Derviş Zaim'in Tuz Gölü'nde gerçekleștirdiği ve birkaç kısa taşıt planından başka mekân görülmeyen -ki bu planlarda da kamera asla aracın içine girmez- Nokta'nın kayda değer bir ara mekâna sahip olduğu söylenemez. Ancak Doğa Üçlemesi'nin ${ }^{4}$ ilk iki filmi Devir ve Balık'ta ara mekânlar tekrar karşımıza çıkar ve hatta Devir, ara mekân kullanımının tipik bir örneğini verir. Bu filmde ara mekân bir karar verme anının gerilimini imler. Her yıl yaylaya çıkan sürülerin köye dönüşünü artık bir yarıșmaya dönüşmüş ritüelle kutlayan bir grup çobanın yarı kurmaca yarı belgesel öyküsüdür Devir. Sürüler köye dönerlerken bir göletten geçirilir; suyu en hızlı ve uyumlu geçen sürü ve sürünün çobanı yarışmayı kazanır. Ritüelin bir parçası olarak, sürünün lider koyunları köyün yakınlarındaki arazide bulunan kırmızı bir kayadan elde edilen toz boyayla boyanmaktadır. Mustafa Çoban (Mustafa Salman) büyük ümitlerle hazırlandığı yarışmayı kaybedince -yarışmada haksız yere ikinci ilan edildiğini düşünmektedir- bunalıma girer. Yarışmadan hemen sonra ağıla giderek içmeye başlar. Sonra sürüsünün lideri olan ve çok sevdiği, kırmızıya boyanmış koyunu da sürüden ayırarak, kesmek amacıyla ağılın dışına çıkarır. Koyunla Mustafa 
Çoban'ın arasındaki gerilim, her ne kadar artık birbirlerinden bir çitle ayrılmış da olsalar gözle görülür hale gelir. Yönetmen, kurgunun/montajın olanaklarını da kullanarak bu ikili arasındaki gerilimi mekânla birleştirir. Mekânın gerilimi çoban ve sürüsü arasındaki gerilimle bir araya gelir, onu güçlendirir ve görünür kılar. Bir ara mekân olarak ağll, Derviş Zaim'in filmografisi boyunca gerçekleştirdiği gibi, gerilimin mekânı olarak işlev görür. Bir yandan film devinimine ve film anlatısına platform sağlarken diğer yandan bizatihi film geriliminin kaynağı haline gelir. Üçlemenin ikinci filmi Balık'ın önemli ara mekânlarıysa balık hali ve kimya malzemeleri deposudur. Küçük bir balıkçı köyünde yaşayan ve geçimini balıkçılıkla sağlayan Kaya (Bülent İnal), hasta, konuşamayan kızı Deniz'in (Myroslava Kostyeva) tedavi masrafları altında ezilmektedir. Düştüğü açmazda kendince bulduğu çözüm, kimyasal maddelerle avlanmaktır. Kaya'nın, balıkları öldüren kimyasal maddeleri satın aldığı depo ve daha sonra avladığı balıkları sattığı balık hali ne iç ne de dış mekânlardır. Her iki yapının da ön cepheleri açıktır; yüksek çatısıyla kimyasal madde deposu neredeyse açık alan izlenimi verir. Buna karşın balık hali de tamamen açık ön cephesi nedeniyle gün ışığıyla aydınlanmakta ve kısmi olarak gölgede kalmaktadır. Kapitalist tahakküm ilişkileri içinde ezilen insanın doğayı tahribi temasını merkeze alan filmin, tam da kapitalist tahakkümü ve doğanın tahribini imleyen bu iki mekânı ara mekânlar olarak tasavvur edilmiştir. Bu ilişkilerin özne üzerinde yarattığı gerilim, bu iki mekânda somutlaşır. Mekânın ikircikli yapısı tahakkümü ve tahribatı işaret eder.

\subsection{Sinemasal Gerilimin Yaratılmasında Kurgu ve Mekân İlişkisi}

"Gerilim kavramı, kurmacayla son derece yakından ilişkilidir. Şu biçimde olması gerekir: Öykü anlatmak gerilim yaratmak demektir ve öykü anlatıcısının sanatı, sıradan konuları ve sonu daha başından bilinen öyküleri ilginç hale getirebilme yeteneğinde yatar" (Thomas Mann'den aktaran Bordwell ve Thompson, 2011, 59).

Mekân sinemasal anlatıya bir platform oluşturmaktadır; Derviş Zaim sineması için de geçerli bir önermedir bu. Biçimsel ve bağlamsal bir değerlendirme yapıldığında iç, dış ve ara mekânların bir yandan sinemasal devinime platform sağladığı ve bir sahne oluşturduğu, diğer yandansa anlatıyla bir arada ve zaman zaman onu güçlendirerek kullanıldığı görülmektedir. Bununla birlikte yönetmen, kurgunun olanaklarını kullanarak bu mekânların arasında gider gelir. Kurgu sayesinde sinemasal devinim farklı mekânları birleștirirken mekân da anlamı taşır hale gelir. Örneğin Tabutta Rövaşata filminde iç ve dış mekânın birbirine bağlanması semboller aracılığıyla gerçekleşir. Sarı Kemal Sade’nin ölümünden sonra, hatırası için yere dökülen şaraptan, inşaatta bir tenekede yanan meyve kasalarının alevine geçilir. Bir kahramanın ölümünü kutsamak için, şarabın tanrılar adına önce toprağa saçılmasına ve sonra kahramanın ölü bedeninin yakılmasına göndermede bulunan bir plandır bu. Bu sembolik anlatı aynı zamanda dış ve iç mekânı birbirine bağlar. Yine aynı filmde, iç mekânda yarım somun ekmeği küçük lokmalarla yiyen Mahsun'dan dış mekândaki sokak köpeğine geçer Derviş Zaim. Mekân, Mahsun'un sefaletini anlatan iki planla bağlanmış olur. Kahvehanede Mahsun'un okuduğu gazetede yer alan haberin fotoğrafındaki arabadan, aynı arabanın sokaktaki görüntüsüne geçilir; bir sonraki planda Mahsun arabayı çalacaktır. Böylesi bir sembolik anlatı Devir filminde de görülür: Önce mühendisin avladığı geyiğin boynuzlarını bir direğe asılmış halde görür izleyici, takip eden plandaysa bir arabanın konsolu üzerine duran, geyik boynuzu şeklinde çatılmış çıtalar vardır. Sahih boynuzla, onun yerine alacak sahte, hem iki planı hem de iki mekânı birbirine bağlar. Balık'ta da semboller ve sembolik 
anlatı mekânları birleştirmeye devam eder. İlk planda, bu küçük öyküde Kaya'nın, büyük anlatıdaysa kapitalizmin sorumlu olduğu yıkımın sembolü ölü balıklar görülür. Bu plan bütün masumiyetiyle akvaryumdaki balığını izleyen Kaya'nın kızı Deniz'in planına bağlanır. Kaya'nın zehirli kimyasallarla avladığı balıkları getirdiği balık hali planlarının tamamı da benzer biçimde bağlanır: Dış mekânda, elde taşınan tek bir balıktan, iç mekândaki balık kasalarına geçilir. Ya da sokakta, elinde bir balıkla görülen Filiz'in planı aynı balığın mutfak tezgâhındaki plana bağlanır. Filmin büyük göstereni olan balık, mekânı bağlayan bir öğe haline gelmiștir. Semboller ve sembolik anlatı, Derviş Zaim sinemasının karakteristik öğelerindendir. Yönetmen sembolleri defaten ara mekânlarla örtüştürür. Bunun sıra dışı bir örneğini Tabutta Rövaşata filminde görürüz. Tabutta Rövaşata'da Mahsun, Reis'in (Tuncel Kurtiz) balıkçı sandalını çalmış, platonik aşkıyla (Ayşen Aydemir) Boğaz gezisine çıkmış, ne var ki Beşiktaş açıklarında kayalıklara çarparak sandalı batırmıştır. Geceyi Rumeli Hisarı'nda eski bir topun içinde uyuyarak geçirir. Derviş Zaim, o günün sabahında Mahsun'u 'topun ağzında' resmeder. Bu örnekte görüldüğü gibi yönetmen, filmlerinde çok katmanlı okumalara olanak sağlayacak biçimde gerçekçiliği, gerçeküstücülük ve sembolizmle bir arada kullanmaktadır.

Filler ve Çimen'de, farklı mekânların kurgu/montajla bağlanması konusunda Derviş Zaim'in daha sonra gerçekleștireceği bazı uygulamaların ilk örneklerine rastlanır. Yoğun bir iç mekân kullanımı da olsa, aslında filmin iç ve dış mekânları iç içe geçmiş gibidir; muğlaktır. Kamera çoğu zaman iç mekânlara dışarıdan, dış mekânlaraysa içerden bakar. Yönetmenin ilk olarak Tabutta Rövaşata'da uyguladığı televizyon ekranı aracılığıyla dış mekâna geçilmesi ilkesi bu filmde de görülür. Kamera önce iç mekânda izlenilen bir televizyon ekranına yaklaşmaya başlar, dış mekân önce televizyon ekranında görülür. Bir sonraki plandaysa artık kamera da dış mekâna çıkmıştır. Modernlik sonrasının mekânı olarak görür Derviş Zaim televizyonu: Bir mekânı, diğerine dâhil eden, başka başka mekânları bir araya getirerek yeni bir mekân oluşturan ortamdır (Zaim, 12 Ocak 2016). Ancak yönetmenin filmografisinde mekânlar arasında bağlantılar kuran tek görsel öğe televizyon değildir. Cenneti Beklerken'de bu işi aynalar üstlenir. Sahne bir rüya mekânında geçer: Eflatun kervansarayın iç mekânındadır; "kâfir resmine" ek yapması talep edildikten sonra baygınlık geçirir. Bu sırada onun arkasında bulunan bir aynaya doğru ileri kaydırma yapılır. Aynada aslında kervansarayın yansımasını görmemiz gerekirken başka bir görüntüyle karşılaşırız. Orada kervansarayın içinin yansısı yerine Eflatun'un ölmüş oğlunun ırmak kenarında durduğu bir zamanın ve mekânın yansıması vardır. Kamera Eflatun'un oğlunun yanından ileriye doğru kaydırma yapmaya devam eder. Eflatun'un oğlunun arkasında bulunduğu bir başka aynaya doğru ilerler. "O aynada ırmak kenarının yansımasının olmasını bekleriz, ama ırmak kıyısı yerine bu kez orada kervansarayın içine dair bir yansıma olduğunu fark ederiz" (Zaim, 2006, 29). Cenneti Beklerken'in rüya mekânında geçen bu sekansta aynalar aracılığıyla üç ayrı zaman ve mekân birbirine bağlanır. Yönetmenin, minyatür sanatına göndermede bulunarak ortaya koyduğu oynak zaman ve oynak mekân kavramsallaştırmasına ${ }^{5}$ denk bir kullanım biçimidir bu. Çoklu zaman ve çoklu mekân üzerine kurulu bu bakış aynalar aracılığıyla tek bir mekânda -bu film için bir rüya mekânında- bir araya gelir. Gölgeler ve Suretler'deyse farklı mekânların birbirlerine bu kez fotoğraflar aracılığıyla bağlanacak, ancak mekân bu kez rüya mekânı değil de gerçek(çi) bir mekân olacaktır. Kamera Ruhsar'ın elindeki bir fotoğrafa odaklanarak ileri kaydırma yapar; çerçeve, fotoğraftaki mekânla dolarken birden fotoğraf hareketlenir ve bu kez kesme 
olmaksızın bir önceki planı örterek onun yerini alır. Yönetmen, yine oynak zaman ve oynak mekân ilkesinden hareket ederek farklı zaman ve mekânları aynı çerçevede, dolayısıyla aynı mekânda bir araya getirmeye çalışmaktadır. Derviş Zaim'in Küşteri Meydanı biçiminde kavramsallaştırdığı ve gölge oyununa göndermede bulunan bir mekân yaklaşımıdır bu. Aynı anda hem zamanı ve hem de farklı mekânları bir araya getiren bir platform. "Ruhsar'ın yaşadığı evin içerisinde bulunan o fotoğraflar odadaki masanın üzerinde öylece duruyorlar ve filmde yer alan karakterlerin geçmişleri ve gelecekleriyle ilişki içindeler" demektedir Zaim (aktaran Çetinkaya, 2010). Derviş Zaim sinematografisinde, "imge taşıyıcıları" denilebilecek görsel öğeler; televizyon ekranları, aynalar ve fotoğraflar, yerleri, karakterler, geçmiş ve geleceği birleştirir. Yönetmen, böylesine bir öykülemeyle, ara mekânları farklı biçimlerde perdeye getirmeye çalışır. Bu örneklerde de gördügümüz gibi, ara mekânlar sadece iç ve dış mekânların arasında kalan ya da bu mekânların kesişimleriyle ortaya çıkan yerler değildir. Fotoğraflar, televizyonlar ya da aynalar gibi, faklı mekân ve zamana ait öğeleri barındıran, bu öğeleri bir araya getirme ve bir arada tutma gücü taşıyan olguları da ara mekânlar olarak değerlendirmek mümkündür. Bu bağlamda ara mekânlar, muğlaklıkların yeridir.

Geleneksel anlatıda "öykü anlatmak gerilim yaratmak demektir". Sinemasal devinim gücünü gerilimden alır; gerilim sinemasal eylemin motorudur. Derviş Zaim sinemasında gerilim çoğu zaman mekânlar arasında gidip gelen planlarla, kurgu/ montajla sağlanır. Tabutta Rövaşata'da kestiği tavus kuşunu pişirmeye hazırlanan Mahsun'un bekçiye yakalandığı ve esaslı bir dayak yediği sekansta planlar -ki tüm bu gerilim bir ara mekânda gerçekleşmektedir- hayattan yediği tüm darbeleri de tekrar bize anımsatarak iç ve dış mekânlar arasında gidip gelir. Devir'de de benzer bir biçimde, ara mekânda hayata dair tüm umutsuzluklarını ve kararsızlıklarını yaşayan Mustafa Çoban'ın gerilimi kameranın kâh ağılın içine, Mustafa Çoban'a yönelmesi kâh ağılın avlusuna, kırmızı koyuna dönmesiyle gerçekliğini bulur. İç ve dış mekânlar kurgu/montajda ardı ardına dizilerek ikilemler, ikircikler yaratılır. Benzer biçimde, filmografisinin başından itibaren, yönetmen için taşıtlar gerilim kaynağıdır: Mahsun'un çalıp durduğu otomobiller, otobüsler, Reis'in teknesi; Filler ve Çimen'de farklı iktidarlara eklemlenen, iktidarla birlikte varlığını bulan lüks taşıtlar, yatlar ve yoksulluğu imgeleyen banliyö treni; Çamur'da Temel'in kamyoneti ve hatta tuzlada bir enkaza dönmüş sandal; Nokta'daki taşıtlar, mafyaya ait lüks otomobil, esnafın toplanıp geldiği minibüs ya da motosikletten bozma taşıt; Gölgeler ve Suretler' in yoğun gerilimlere sahne olan otomobilleri ve otobüsü; Devir ve Balık'ın kamyonetleri... Birer ara mekân olan bu taşıtlar kurgunun/montajın olanaklarıyla gerilimi de taşıyan bir platform halini alır. Bu durumun belki de en iyi örneği Gölgeler ve Suretler'de karşımıza çıkar. Filmin temel gerilimleri bu sekansta oluşur ve film sonuna kadar çözülemeyecek çatışmalar yine bu sekansta kurulur.

Sekans, filmin giriş sekansının hemen ardından başlar: Ruhsar ve hasta babası Karagözcü Salih, yaşadıkları Yukarı Gyges köyü Rum askerleri tarafından boşaltılınca hemen yakınlarındaki Aşağı Gyges köyüne, Salih'in kardeşi Veli'nin (Osman Alkaş) yanına sığınmışlardır. Așağı Gyges, Türklerin azınlıkta kaldıkları bir köydür ve günden güne bu köyde de bir çatışma yaşanması olasılığı artmaktadır. Dolayısıyla Salih ve Ruhsar geçici olarak bu köydedir ve asıl niyetleri şehre gitmektir. Veli'nin evinde geçirdikleri ilk gecenin ardından, sabahla beraber sekans başlar. Salih, Veli ve Ruhsar bir Rum kadınının, Anna'nın (Popi Avraam) kullandığı taşıtla şehre gitmek 
için hazırlanırlar. Salih bu sırada elinde tuttuğu gölge oyunu figürlerini Veli'ye verir ve bir çukur kazıp gömmesini yoksa bu figürlerin büyük uğursuzluk getireceğini söyler. Anna gelir, Salih ve Ruhsar arabaya biner ve hareket ederler; Veli arkalarından bakar ve onlar uzaklaştıktan sonra elindeki figürleri duvarın dibine atarak avluya girer. Bu sırada Anna, Salih ve Ruhsar'ın içinde bulunduğu taşıt kır yollarında şehre doğru ilerlemektedir; kamera tüm bu eylemi dışarıdan kaydeder. Sonra çok kısa bir planla, kamera taşıtın içine girer ve yolun Rum askeri tarafından kesildiği, muhtemelen Türk olan iki kişinin de bu askerler tarafından dövüldüğü görülür. Salih ve Ruhsar panik halinde taşıtı terk ederek yolun kenarındaki ağaçlık alanda gözden kaybolurlar; bu sırada Anna, Rum askerleriyle baş başa kalır. Neredeyse beş dakikalık bu dış mekân planında kamera tek bir kez, tam da Rum askerlerinin yolu kestiğinin anlaşıldığı anda aracın içine girer. Salih ve Ruhsar'ın arabayı terk edip ağaçların arasında kaybolmasıyla birlikte de iç ve dış mekânların kurgulanmasıyla/ montajıyla yaratılan gerilim planları başlar.

İlk gerilim planı Salih'le Ruhsar'ın sığınacakları yer aramalarını gösteren bir plandır. Dalları yere kadar dökülen bir ağacın altında, küçük bir mağara, bir kovuk bulurlar. Kovuğa saklanma niyetindedirler. Bu planı ilk kovuk planı takip eder (Şekil 3, 52. plan); yaklaşık beş saniyelik bu iç mekân planında Ruhsar'ın kovuğa girişi görülür. Yarı aydınlık - yarı karanlık, duvarlarında güneş ışığıyla gölgelerin birbirine karıştığı bir mekândır burası. Bu iki planı giderek kısalan dış ve iç mekân planları takip eder; kısa ve iç içe geçmiş mekân planlarıyla gerilim giderek yükselir. Sonraki dış mekân planında (53. plan) Salih'in kovuğu gizlemeye çalıştığı görülür; yaklaşık dört saniyelik kısa bir plandır. Bu planı bütün bu sekansın en kısa iç mekân planı takip eder: Ruhsar kovuğun içinde, kovuğun girişini gizlemeye çalışan babasını izlemektedir. Bu plan sadece bir saniye sürer. Bu kısa iç mekân planını yine oldukça kısa bir dış mekân planı takip eder; dört saniyelik planda Salih'in kovuğa girişi ve bu sırada ağacın dallarıyla kovuğun ağzını kapatışını görürüz. Takip eden 56 numaralı iç mekân planında Salih'i kovuğun içinde, Ruhsar'ın yanında görürüz. İki saniyelik planda baba ve kızın bir nebze rahatladığı, ancak tehlikenin henüz geçmediği ve bu nedenle gerilimin devam ettiği bellidir. Tehlike, bir sonraki planda açığa çıkar: Kovuğun hemen ağzından dış mekâna bakmakta olan kamera, hafif bir çevrinme hareketiyle yükselir ve ağaçlık alanın önündeki patikadan iki Rum askerinin koşarak geçtiği görülür. Askerler, baba ve kızı aramaktadır; dört saniyelik plan bu gerilimi vermeye yetmiştir. Yönetmen, basit bir kesmeyle gerilimi yine iç mekâna taşır: Üç saniyelik planda Salih ve Ruhsar, kendilerini arayan askerlerin ayak seslerini duymuşlardır, gerilim doruktadır. Yirmi beş saniyelik bir dış mekân planına geçilir (59 ve 60 numaralı planlar): Baba ve kızı arayan askerler patikadan ayrılarak kovuğun da bulunduğu ağaçlık alana gelirler. Ancak kovuğu göremez ve uzaklaşırlar. Yönetmen tekrar iç mekân planına geçer. 61 numaralı, yaklaşık dört saniyelik planda uzaklaşan askerlerin ayak seslerini dinleyen Salih ve Ruhsar görülür. Altıncı dış mekân planında yönetmen tekrar dışarı çıkar; ortalık sessizdir, kuş cıvıltılarından başka bir şey duyulmaz. Kamera bir çevrinme hareketiyle yükselir ve bütün sükûnetiyle Akdeniz görülür. Kamera tekrar kovuğun içine girdiğinde baba ve kızın bütün bu gerilim sekansındaki ilk diyaloguna tanıklık ederiz. Bu diyalog, aynı zamanda ikinci gerilim bölümünün de başlangıcıdır. 


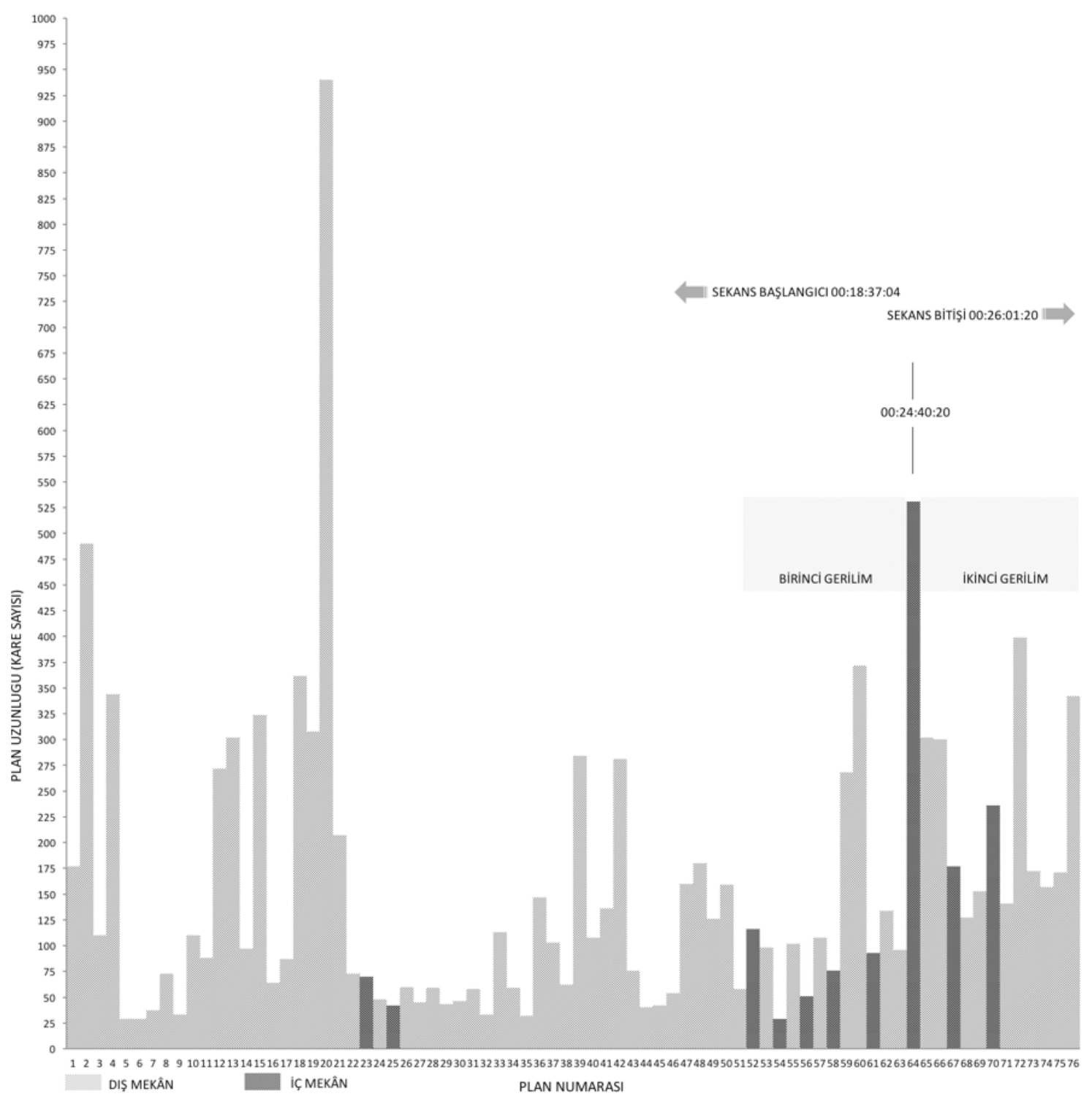

Şekil 3: Derviş Zaim Sinematografisinde Mekân Aracılılı̆̆ıyla Gerilimin Yaratılması (Gölgeler ve Suretler, 2011)

Rum askerlerinin Salih ve Ruhsar'ın peşine düştüğü bu ilk gerilim bölümü filmin iki temel geriliminden biridir. Rumlar ve Türkler arasındaki çatışma bu gerilim bölümünde temsil edilir. Filmin bir anlatısı budur; diğer bir anlatıysa baba ve kızın ayrı düşmesi üzerine kuruludur ki bu ayrılığın yarattığı gerilim yine bu mekânda vuku bulacaktır. 64 numaralı iç mekân planında baba ve kızın konuşmasına tanıklık ederiz. "Durumu öğrenmemiz lâzım kızım" der Salih; nihayetinde, sonsuza kadar o kovukta bekleyecek halleri yoktur. Ne var ki Ruhsar dışarıdan korkmaktadır, çıkmayı istemez. Salih, "Korkma kızım, ben hemen geliyorum" der ve kovuktan çıkar, Ruhsar yalnız kalır. Yirmi bir saniyelik bu uzun iç mekân planına bütün bu sekans boyunca ilk kez müzik de dramatik bir öğe olarak eşlik eder ve aynı zamanda gerilimi de arttırır. 65 ve 66. dış mekân planlarında, önce yakın sonra uzak ölçekte, kovuktan çıkan Salih'i görürüz. Salih kovuğun girişini tekrar ağaç dallarıyla örter ve patikadan koşarak uzaklaşır. Takip eden iç mekân planında Ruhsar kovukta endişeyle oturmaktadır; göreceli olarak uzun, ancak eylemsiz bir plandır bu. Zaman, babasını bekleyen Ruhsar'la beraber donmuş gibidir. Yönetmen bir kez daha dış mekâna 
çıkar; ortalık sakindir ve kuş seslerinden başka bir şey duyulmamaktadır. Yeniden iç mekâna girdiğimizde (70. plan) Ruhsar'ın kovuktan çıkmaya karar verdiğini anlarız; oturduğu yerden kalkar ve kovuğun ağzına yönelir. Bu sekans için son kez yönetmen dış mekâna geçer: Ruhsar kovuktan çıkar, patikada koşarak ilerler, kamera yükselir. Bir kez daha Akdeniz'e ve Kıbrıs'a bakarız; her iki mekân da ıssız ve sakindir. Buna bağlanan planda zaman ve mekân değişir; güneş batmak üzeridir ve akşamın alaca karanlığında Ruhsar köye gelmiștir. Evin avlusuna girmek üzereyken, sabah Veli'nin duvar dibine attığı Karagöz figürlerini görür. Uğursuzluk kehaneti, geri döndürülemez bir biçimde gerçekleșmiştir. Figürleri alır, avluya girer, evin kapısını çalar ve sekans sona erer. Yaklaşık sekiz dakikalık, iki ayrı gerilimi yansıtan bu sekans, Derviş Zaim sinemasında mekân ve gerilim öğelerinin nasıl bir arada kullanılacağını ve mekânın gerilimi nasıl taşıyabileceğini gösterir. Benzer gerilim sekanslarında ve iç ve dış mekânlar arasında gidip gelen kurgu/montaj yapısının, filmografisi boyunca müteakiben görüldüğünü tekrar etmek gerekir. Yönetmen, iç ve dış mekân arasındaki gerilimi öykünün gerilimine ekler. Gerilim bir yandan mekânları birleştiren bir öğe haline gelirken, mekân da hem gerilime hem de filmin anlatısına bir platform teşkil eder. Mekân, gerilim ve anlatı, üçlü bir ilişki içinde birbirlerini gerçekleştirerek ilerler.

\section{Sonuç}

Derviş Zaim'in sinemasal mekânlarının, mekânın bir sahne ya da anlatının platformu olarak kullanılması bağlamında, biçimsel ve bağlamsal çözümleme yöntemleriyle değerlendirildiği bu çalışmada öncelikle sinemasal manzaralar ele alınmıştır. Çalışmada, "sinemasal mekânın sinemasal eylemin platformu olduğu; olayların, olguların ve karakterlerin bir mekânda yer aldığı ve sinemasal eylemin sinemasal mekânda devindiği” önermesinden yola çıkılarak Derviş Zaim'in filmografisinde sinemasal mekânların, sinemasal manzaraların durumu yorumlanmıștır. Sinemasal manzaralar öykünün tutunacakları alanlardır; dramatik anlatının ilerleyebileceği bir ortam sağlar. Bununla birlikte manzaralar, tıpkı sinema sanatının kendisi gibi görsel ve algısal açılardan toplumsal olarak inşa edilmektedir. Manzaralara yaklaşımımız ve anlayışımız kültürel, davranışsal ve deneyimsel olarak biçimlenmiştir. Derviş Zaim'in sinemasal manzaralarıssa sinemasal eyleme bir platform sağlamakta; bazen anlatıya yeni bir anlam eklemek için, anlatının öğesi olarak filmde yer almakta, bazen de sadece eylemin gerçekleștiği bir düzlem, bir sahne olarak işlev görmektedirler. Yönetmenin mekânı ele alışı, temel işlevi bakımından tiyatrodaki sahnelemeye benzer. Ancak Derviş Zaim sinemasında, hem tiyatrodan hem de sinemanın geleneksel mekân kullanımından faklı bir durum söz konusudur. Yönetmen iç ve dıș mekânların yanı sıra, ara mekân olarak kavramsallaștırabileceğimiz mekânları belirgin bir biçimde kullanmaktadır. Ara mekânlar, ne tam olarak dış ne de iç mekân sayılabilecek yerlerdir. Açık alan değildirler ama aynı zamanda kapalı (iç) mekânlar olarak da sınıflandırılamazlar. Yönetmen, bu mekânların muğlaklığından sinemasal gerilimi yaratmak için etkin bir biçimde yararlanır. Mekâna dair muğlaklık, yönetmenin özyaşam öyküsüne de denk bir biçimde sinemasal anlatısında önemli yer tutar. Sadece iç ve dış mekân arasındaki geçişlerle değil, geleneksel mekân anlayışının dışında kalan taşıtların kullanımıyla ya da televizyon, fotoğraf ya da ayna gibi imge taşıyıcısı araçlarla da ara mekânlar inşa edilir. Kaygan, sabit bir referans noksanın olmadığı, tıpkı yönetmenin çocukluğunu geçirdiği Kıbrıs gibi, öznenin tutunamayacağı mekânlardır ara mekânlar. 
Çalışmada bu önermelerle birlikte, Derviş Zaim'in sinematografisi mekânın temel kullanımı bağlamında irdelenmiş; mekân, bir sahne ya da anlatının bir platformu olarak çözümlenmeye çalışılmıştır. Bunun içinse öncelikle daha senaryo yazım aşamasında karşımıza çıkan, mekânın sinema sanatındaki en temel ayrımına göre bir değerlendirme yapılmış ve yönetmenin filmografisi sinemasal anlatının mekânla ilişkisini değerlendirebilmek için iç, dış ve ara mekânlar bağlamında çözümlenmiştir. Yönetmenin filmleri biçimsel çözümlemeyle, mekân bağlamında planlarına ayrılmış; $i c ̧, d ı s ̧$ ve jenerik planlarına göre dökümü yapılmış, sınıflandırılmış ve nicel veri elde edilmiştir. Bu nicel veriden yararlanılarak Derviş Zaim'in sinematografisi, mekânın temel kullanımı bağlamında değerlendirilmiş; mekân, bir sahne ya da anlatının bir platformu olarak çözümlenmiştir. Biçimsel çözümleme aracılığıyla iç, dış ve ara mekânların birbirleriyle ve diğer mekânlarla ilişkisi değerlendirilerek, bu ilişsilerin film anlatısıyla bağı ortaya konmaya çalıșılmıștır. Derviş Zaim sinemasında mekân bu bağlamda, film deviniminin asli öğesi ve anlatının platformu olarak, anlatının devinimine denk bir biçimde kullanılmaktadır. Bunlarla birlikte iç ve dış mekân geçişleriyle sinemasal anlatı zenginleştirilmekte ve mekân sadece sinemasal anlatıya platform oluşturmakla kalmayarak bizatihi sinemasal gerilimi oluşturmak için de kullanılmaktadır. Diğer yandan yönetmen, iç ve dış mekân arasındaki gerilimi öykünün gerilimine taşımaktadır. Gerilim bir yandan mekânları birleştiren bir öğe haline gelirken, mekân da hem gerilime hem de filmin anlatısına bir platform teşkil etmektedir. Mekân, gerilim ve anlatı, üçlü bir ilişki içinde birbirlerini gerçekleştirerek ilerler. Bütün bunlardan sonra, salt teknik bir değerlendirmede bile yönetmenin mekânı sinemasal anlatının etkin bir öğesi olarak sinemasına dâhil ettiğini söylemek mümkündür. Daha bu ilk değerlendirmeyle birlikte, yönetmenin mekânı film anlatısının asli öğesi olarak yapıtlarına dâhil ettiği görülmektedir.

Gerçekleştirilen çözümlemelerden sonra, Derviş Zaim sinemasında mekânın, anlatının platformu olarak değerlendirilmesi bağlamında özetle şunlar söylenebilir: (1) Derviş Zaim'in sinemasal manzaraları öncelikle sinemasal eyleme bir platform sağlamakta; bazen anlatıya yeni bir anlam eklemek için, anlatının öğesi olarak filmde yer almakta, bazen de sadece eylemin gerçekleştiği bir düzlem, bir sahne olarak işlev görmektedirler. Bu bakımdan Derviş Zaim'in sinemasal manzaralara yaklaşımı, sinema sanatının genelinden farklı değildir; yönetmenin mekânı ele alışı, temel işlevi bakımından tiyatrodaki sahnelemeye benzemektedir. Ancakyönetmen, ara mekânları kullanım biçimiyle bunu aşmaktadır. Derviş Zaim sinemasında mekân bu bağlamda, film deviniminin asli öğesi, anlatının platformu olarak, anlatının devinimine denk bir biçimde kullanılmaktadır. Yönetmenin yöneldiği temalara göre -örneğin insan-doğa çatışması- sinemasal mekânlarının da dönüşüme uğradığı görülmektedir. Örneğin Devirve Balık'la birlikte -hâlihazırda tamamen dış mekânda gerçekleştirilen Nokta'yı istisna kabul edersek- dış mekânlar yoğun bir biçimde kullanılmaya başlanmıștır; (2) Bunlarla birlikte iç ve dış mekân geçişleriyle sinemasal anlatı zenginleştirilmekte ve mekân sadece sinemasal anlatıya platform oluşturmakla kalmayarak sinemasal gerilimi görünür kılmak için de kullanılmaktadır. Yönetmen, iç ve dış mekân arasındaki gerilimi öykünün gerilimine taşımaktadır. İç ve dış mekânlar arasında taşınan gerilim, bir yandan mekânları birleştiren bir öğe haline gelirken, mekân da hem gerilime hem de filmin anlatısına bir platform teşkil etmektedir. Mekân, gerilim ve anlatı, üçlü bir ilişki içinde birbirlerini gerçekleştirerek ilerler. Yönetmen için mekân, -kurgunun/montajın olanaklarından da yararlanılarak- sadece film anlatısına bir platform oluşturmakla kalmamakta, aynı zamanda bizatihi gerilimin 
kaynağı olarak anlatıya dâhil olmaktadır. Bu bakımdan, en yalın kullanım biçimiyle bile mekân, Derviş Zaim sinemasının aslî öğesi haline gelmektedir.

\section{Notlar}

1 İlginçtir; Derviş Zaim, kendisinin ve sinemasının, Türk sinemasındaki konumunu dahi coğrafi bir terimle açıklamaktadır: Alüvyonik Sinema. Türk sinema tarihinin 1990 sonrasını betimlemek için kullanılan genç, yeni ya da bağımsız sinema ifadelerine karşın "alüvyon" kavramının çok daha açıklayıcı olduğunu düşünmektedir. Alüvyon, "Doksanlarda beliren yeni yönetmenlerin hem aynı yöne aktıklarını anlatma kabiliyetine sahip olmakta; hem de aralarında farklı biçimler alabilen bağlara işaret etmektedir. Bu dönemde beliren yönetmenler, bir alüvyonu oluşturan kollar gibi birbirlerinden bağımsız ama birbirlerine paralel biçimlerde faaliyetlerini sürdürmekte, kimi zaman bir alüvyonun kollarıymışçasına birleşip, bazen ayrılmaktadırlar. Alüvyon kavramı, bazen farkı bazen benzer tarzlara, üretim, finansman, dağıım vs. biçimlerine sahip bu grubu, dinamikliği ve farklııklarılla yetkinlikle tanımlamaktadı" (Zaim, 2008, 48, 50).

${ }^{2}$ DVD formatında kaydedilmiş bir filmi Adobe Premiere Pro CS5 ile planlarına ayırmak için, filmi öncelikle AVI, MPEG ya da M4P gibi sayısal video formatlarından birine dönüştürmek gerekmektedir. Bu çalışma kapsamında, Derviş Zaim'in filmlerini DVD formatından MPEG formatına dönüştürmek için iSkysoft iMedia Converter adlı yazııım kullanılmıştır.

3 Tablo 1, Şekil 1, Şekil 2 ve Şekil 3 oluşturulurken, filmlerde görülen ara mekânlar şu biçimde iç ve dış mekânlara dâhil edilmiştir: Örneğin pekâlâ yapay aydınlatmayı gerektiren çadır, mağara ya da kuyu gibi mekânlar iç mekân olarak değerlendirilirken çardak ya da ağıl gibi doğal ışıkla aydınlanan mekânlar dış mekânlara dâhil edilmiştir. Bununla birlikte, otomobil, kamyonet, otobüs ya da tren gibi taşıtlar kameranın konumuna göre değerlendirilmiştir. Basit bir biçimde, kamera eğer aracın içindeyse iç mekân, kamera aracı dışarıdan gösteriyorsa dış mekân olarak sınıflandırılmıştır.

4 Üçleme, 2016 ylında gösterime giren Rüya filmiyle tamamlanmıştır.

${ }^{5}$ Oynak zaman ve oynak mekân kavramsallaştırması, yönetmenin ilk filminden itibaren uyguladığı, ancak ilkelerini Cenneti Beklerken filminde ortaya koyduğu; gücünü geleneksel minyatür sanatından, minyatür sanatının zaman ve mekâna yaklaşımından alan kavramsallaştırmadır. Derviş Zaim, minyatürlerin Batıı resim sanatının aynı döneminde gerçekleştirilen örneklerinin aksine, farklı zaman ve mekânları bir arada resmetme gücüne dikkat çekmektedir. Minyatürlerde mekân, neredeyse her defasında farklı şekilde nakşedilebilmekte, farklı zamanlarda, farklı yerlerde gerçekleşen olaylar ise aynı mekân ve zamanda bir araya getirilmektedir. Yönetmen buradan hareket ederek ve biçem ve içerik arasında organik bir ilişkinin söz konusu olabileceğini de düşünerek film tekniğini ve estetiğini oynak zaman ve oynak mekân kavramsallaştırması etrafında kurmaya çalışır.

\section{Kaynakça}

Balázs, B. (2013). Görünen İnsan. O. Kasap (çev.), Ankara: Say.

Bordwell, D. (2006). The Way Hollywood Tells it: Story and Style in Modern Movies. California: University of California Press.

Bordwell, D. \& Thompson, K. (2011). Film Sanatı - Bir Giriş. E. S. Onat ve E. Yılmaz (çev.), Ankara: De Ki.

Bozdemir, B. (2008). Derviş Zaim Noktayı Koydu. Cinedergi Aylık Sinema Dergisi, 4, 14-19.

Corrigan, T. \& White, P. (2012). The Film Experience: An Introduction (3. Baskı). Boston \& New York: Bedford / St. Martin's.

Çetinkaya, T. (2010). Zaim'le Vicdan ve Hakikat'in Peşinde. Modern Zamanlar Sinema Dergisi, 18.

Deniz, T. (2011). Derviş Zaim: "Yaratmaya Çalıştığım Sinemada Değer Üretme Çabası Var”. Ayşe Pay (Ed.), Yönetmen Sineması: Derviş Zaim (2. Baskı) içinde (89107). İstanbul: Küre.

Eisenstein, S. (2006). Sinema Dersleri. E. Ayça (çev.), İstanbul: Agora.

Escher, A. (2006). The Geography of Cinema - A Cinematic World. Erdkunde, 60 (4), 307-314. 
Elsaesser, T. \& Buckland, W. (2002). Studying Contemporary American Film: A Guide to Movie Analysis. New York: Oxford University Press.

Lukinbeal, C. (2005). Cinematic Landscapes. Journal of Cultural Geography, 23 (1), $3-22$.

Barsam, R. M. \& Monahan, D. (2010). Looking at Movies: An Introduction to Film (3. Baski). Londra: W. W. Norton \& Company.

Pramaggiore, M. \& Wallis, T. (2008). Film: A Critical Introduction (2. Baskı). Londra: Laurence King.

Ryan, M. \& Lenos, M. (2012). Film Çözümlemesine Giriş - Anlatı Sinemasında Teknik ve Anlam (E. S. Onat). Ankara: De Ki.

Zaim, D. (1995). Ares Harikalar Diyarında. İstanbul: AFA.

Zaim, D. (2004). Derviş Zaim: Sanat Belirli Tercihlerin Tarihidir. Berke Göl, Yamaç Okur, Nadir Öperli (Ed.), Sinema Söyleşileri: Boğaziçi Üniversitesi Mithat Alam Film Merkezi Söyleşi, Panel ve Sunum Yıllığı 2003 içinde (37-82). İstanbul: Boğaziçi Üniversitesi Yayınevi.

Zaim, D. (2006). Cenneti Beklerken: 'Yönetmenin Bakış Açısı'. Altyazı Aylık Sinema Dergisi, 57, 22-25.

Zaim, D. (2008). Odaklandığın Şey Gerçeğindir: Türkiye Sineması, Alüvyonik Türk Sineması ve Uluslararası Kabul 1. Bölüm. Altyazı AylıkSinema Dergisi, 78, 48-55.

Zaim, D. (12 Ocak 2016). Kişisel Görüşme.

Zaim, D. (13 Ocak 2016). Kişisel Görüşme.

\section{Filmler}

Zaim, D. (Yönetmen/Senaryo Yazarı). (1996). Tabutta Rövaşata [Film]. Türkiye: İstisnai Filmler ve Reklamlar Yapım.

Zaim, D. (Yönetmen/Senaryo Yazarı). (2001). Filler ve Çimen [Film]. Türkiye: Panfilm Filmcilik.

Zaim, D. (Yönetmen/Senaryo Yazarı). (2003). Çamur [Film]. Türkiye ve İtalya: Marathon Film ve Downtown Pictures Ortak Yapımı.

Zaim, D. (Yönetmen/Senaryo Yazarı). (2007). Cenneti Beklerken [Film]. Türkiye ve Kanada: Marathon Film, Sarmaşık Sanatlar ve Tivoli Film Production Ortak Yapımı.

Zaim, D. (Yönetmen/Senaryo Yazarı). (2008). Nokta [Film]. Türkiye: Marathon Film ve Sarmaşık Sanatlar Ortak Yapımı.

Zaim, D. (Yönetmen/Senaryo Yazarı). (2011). Gölgeler ve Suretler [Film]. Türkiye: Marathon Film ve Yeşil Film Ortak Yapımı.

Zaim, D. (Yönetmen/Senaryo Yazarı). (2012). Devir [Film]. Türkiye: Marathon Film.

Zaim, D. (Yönetmen/Senaryo Yazarı). (2014). Balık [Film]. Türkiye: Marathon Film.

Zaim, D. (Yönetmen/Senaryo Yazarı). (2016). Rüya [Film]. Türkiye: Marathon Film ve Yeşil Film Ortak Yapımı. 